\title{
HELP ME HELP YOU: WHY CONGRESS'S ATTEMPT TO COVER TORTS COMMITTED BY INDIAN TRIBAL CONTRACTORS WITH THE FTCA HURTS THE GOVERNMENT AND THE TRIBES
}

\author{
JOSEPH W. GROSS*
}

Since the Nixon Administration, the U.S. government has attempted to promote tribal self-determination among Native Americans. Under the Indian Self-Determination Act, the tribes can enter into agreements with the federal government to take over services previously provided to the tribes by the Bureau of Indian Affairs (BIA). By entering into these contracts, the tribes have been able to administer a wide variety of services, including construction and law enforcement, which bring income and employment to Indian country. These contracts do not always run smoothly, however, and sometimes people get injured. Under a series of amendments to the Indian Self-Determination Act, when tribal contractors commit torts, the federal government steps in and defends the tribal contractors under the Federal Tort Claims Act (FTCA) as if they were employees of the government. The government pays out any settlements or judgments from the Judgment Fund. This scenario is a complete departure from the traditional FTCA rule whereby contractors are only treated as government employees in exceedingly limited circumstances.

In hastily extending the FTCA to cover tribal contractors, Congress contravened FTCA jurisprudence in theory and in practice. Congress

* Senior Articles Editor, American University Law Review, Volume 62; J.D. Candidate, May 2013, American University Washington College of Law; B.A., Political Science, 2008, University of Pennsylvania. Many thanks to Professor Paul Figley for his guidance and mentorship in bringing this idea to fruition and to my fiancée Stacey for her love and patience throughout the process. Thanks also to Gail Johnson and Conor Kells for encouraging me to explore this topic. Thanks to my family for their constant support in all of my endeavors. I am grateful to the editors and staff of the American University Law Review for their meticulous edits and thoughtful suggestions. Any remaining errors are mine alone. 
intended to help the tribes avoid having to buy costly insurance by directly assuming liability under the FTCA. While perhaps well-intentioned, the result is a system of perverse incentives and a string of inconsistent decisions. Courts struggle to apply the FTCA's waiver of the federal government's sovereign immunity to the tribes, which remain separate sovereigns that retain some of their own sovereign immunity. The arrangement also creates problems in determining whether tribal contractors are within the scope of their employment and undertaking discretionary functions. Furthermore, the statutory scheme creates the potential for tribal law to govern the United States' tort liability and may have inadvertently created a loophole for the intentional torts of tribal law enforcement officers. The end result of this untenable situation is that savry tribes recognize the unpredictability of the FTCA protection and purchase private insurance anyway, sometimes with federal contract support funds. This is the exact result Congress hoped to avoid.

Congress should end the experiment of extending the FTCA to cover tribal contractors and replace it with subsidized private insurance. This new arrangement would simplify the process for potential claimants and keep the government from having to pay the duplicative costs of insurance and judgments.

\section{TABLE OF CONTENTS}

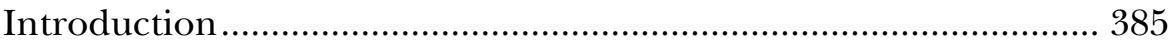

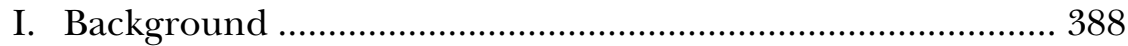

A. Federal Tort Claims Act ............................................... 388

B. Snyder Act .................................................................. 390

C. Indian Self-Determination Act....................................... 392

D. Indian Law Enforcement Reform Act ........................... 395

E. Congressional Proposals for Reform .................................. 396

II. Extending the FTCA to Claims Against Tribal Contractors

Is a Poor Fit.

A. Sovereign Immunity: Extending the FTCA to Tribal Contractors Contravenes the Principles of Sovereign Immunity by Having a Waiver of One Sovereign's Immunity Protect Another Sovereign

1. Theoretical problems ................................................ 401

2. The discretionary function exception ...................... 404

B. Scope of Employment: Applying the FTCA to Tribal Contractors Makes It Difficult To Determine if Tribal Employees Are Acting Within the Scope of Employment ............................................................... 408

1. Non-traditional tribal employees .............................. 409

2. Indian country .................................................... 412

C. Contractors: Covering Tribal Contractors Contravenes the FTCA's Clear and Longstanding Exclusion of Government Contractors............................... 416 
D. Law Enforcement: FTCA Coverage of Tribal Contractors Makes the United States Liable for Some Serious Abuses While Barring Other Actions that Would Proceed if a Traditional Federal Employee Injured the Victim

E. Law of the Place: Covering Tribal Contracts with the FTCA Raises Problematic Choice-of-Law Issues.............. 427

1. FTCA choice-of-law jurisprudence ............................ 427

2. Practical concerns with applying tribal law in FTCA suits

3. Using state choice-of-law rules to apply tribal law ...... 438

III. Suggestions for Reform: Congress Should Replace FTCA Coverage for Tribal Contractors with Subsidized Private Insurance

\section{INTRODUCTION}

In 2007, Mildred Garcia pulled her car off the road in rural Arizona to take a rest when a patrol car driven by a tribal police officer from the Navajo Nation Department of Public Safety swerved off the road and slammed into her car. ${ }^{1}$ Ms. Garcia had to be extracted from the wreckage using the "jaws of life" and suffered severe trauma, including injuries to her spine. ${ }^{2}$ The tribal officer, clad in shorts and a t-shirt, had consumed an 18-pack of beer and a quart of rum prior to blacking out and crashing his cruiser into Ms. Garcia's car. ${ }^{3}$ Smelling strongly of alcohol, the officer eventually admitted to being under the influence. ${ }^{4}$ The tort victim and her family brought a lawsuit, but rather than suing the officer or the tribe, the family sued the United States. ${ }^{5}$

Although the United States had no involvement in the tribal officer's hiring, training, or supervision, a federal district court in Arizona found the officer to be acting as a federal employee within the scope of his employment because of a series of laws governing tribal contracting with the United States. ${ }^{6}$ As a result, the court denied the United States' motion for summary judgment in several key parts, and the federal government agreed to pay a hefty

1. Garcia v. United States, No. 3:09-CV-08033 JWS, 2011 WL 285860, at *1 (D. Ariz. Jan. 27, 2011).

2. Id. at $* 2$.

3. Id. at *1-2.

4. $I d$. at $* 2$.

5. Id. at *4.

6. See id. at *5 (noting that Congress extended the Federal Tort Claims Act (FTCA) to make the United States liable for torts committed by tribal contractors within the scope of their employment to limit the liability incurred by the tribes). 
settlement. ${ }^{7}$ Potential payouts like this, encouraged through federal legislation defining the tribal contractor relationship, come at a time when lawmakers clamor to cut government spending deemed wasteful and excessive. ${ }^{8}$

Since the 1970s, the United States' policy towards the Indian tribes has been to encourage self-government by allowing the tribes to take over programs formerly administered by the Bureau of Indian Affairs (BIA) through the Indian Self-Determination and Education Assistance Act ${ }^{9}$ (Self-Determination Act). ${ }^{10}$ On reservations and tribal lands across the country, the tribes have been taking advantage of this policy, contracting to take over programs such as local law enforcement previously provided to the tribes by the government. ${ }^{11}$ The transition to self-determination, however, has not been seamless.

Major issues arise when tribal contractors commit torts while carrying out these contracts. Instead of carrying insurance like most government contractors, Congress created a legal fiction whereby tribal contractors are deemed to be employees of the federal government covered by the Federal Tort Claims Act ${ }^{12}$ (FTCA), which provides a limited waiver of the United States' sovereign immunity. ${ }^{13}$ That means the United States can be held liable for judgments against tribal contractors even though it has little-to-no involvement in their hiring or supervision. ${ }^{14}$ This arrangement can leave the

7. See id. at *9 (granting the plaintiff's motion for summary judgment on the issue of whether the officer was within the scope of his employment and denying the United States' motion for summary judgment). Ultimately, Plaintiff's counsel failed to follow critical court filing deadlines and the case was dismissed. Garcia v. United States, No. 3:09-CV-08033-JWS (D. Ariz. May 22, 2012) (order dismissing case).

8. See Helene Cooper, Obama Offers Plan to Cut Deficit by Over $\$ 3$ Trillion, N.Y. Times, Sept. 18, 2011, http://www.nytimes.com/2011/09/19/us/politics/obamaplan-to-cut-deficit-will-trim-spending.html (outlining President Obama's deficit reduction plan).

9. Pub. L. No. 93-638, 88 Stat. 2203 (1975) (codified as amended at 25 U.S.C. $\S \S 450-458$ ddd-2 (2006 \& Supp. IV 2011)).

10. See Special Message to the Congress on Indian Affairs, PUb. PAPERs 564, 56468 (July 8, 1970) (announcing the Nixon Administration's new policy shift towards tribal self-determination); Thomas W. Christie, An Introduction to the Federal Tort Claims Act in Indian Self-Determination Act Contracting, 71 MonT. L. Rev. 115, 116 (2010) (tracing the history of the Self-Determination Act).

11. See Blake R. Bertagna, Reservations About Extending Bivens to Reservations: Seeking Monetary Relief Against Tribal Law Enforcement Officers for Constitutional Violations, 29 PACE L. REV. 585, 587 (2009) (suggesting that Congress specifically passed the Indian Law Enforcement Reform Act (ILERA) to facilitate Self-Determination Act contracts for tribal law enforcement).

12. Federal Tort Claims Act, ch. 753, §§ 401-424, 60 Stat. 812, 842-47 (1946) (codified as amended in scattered sections of 28 U.S.C.).

13. See infra Part I.A (discussing the FTCA's history and its relation to the concept of sovereign immunity).

14. See, e.g., Red Elk ex rel. Red Elk v. United States, 62 F.3d 1102, 1104, 1108 (8th Cir. 1995) (finding the United States liable when a poorly trained tribal police officer 
United States financially responsible even when tribal contractors, like the officer who hit Ms. Garcia, commit blatant abuses. ${ }^{15}$

Some courts have recognized the problem of holding the United States responsible for tribal contractors over whom it has little control and have drawn fine lines to protect the United States from liability in certain situations involving law enforcement. ${ }^{16}$ Although these decisions are friendlier to the public fisc, ${ }^{17}$ the tort victims lose the recourse they would have had if the tortfeasor worked for the U.S. government directly instead of pursuant to a tribal contract. ${ }^{18}$ The resulting uncertainty from these decisions undercuts Congress's decision to extend FTCA protection to the tribes.

This Comment examines the purposes and history of the FTCA as well as the laws, like the Self-Determination Act, that govern tribal contracting and proposals for reform. This Comment then argues that extending the FTCA to cover torts committed by SelfDetermination Act contractors contravenes the purpose of the FTCA. The analysis proceeds by addressing specific provisions relating to sovereign immunity, scope of employment, contractors, law enforcement, and choice of law. Part I describes the historic development of the laws governing tribal contracting and the extension of the FTCA to cover Indian contractors. Part II argues that using the FTCA to cover Indian contractors is a poor fit and that the results undermine Congress's reasons for doing so. Part III

raped a minor); Garcia v. United States, No. 3:09-CV-08033-JWS, 2011 WL 285860, at *1 (D. Ariz. Jan. 27, 2011) (denying the United States' motion for summary judgment when an officer blacked out and crashed his police car into another motorist); see also infra Part II.C (discussing contractor liability under the FTCA and the difficulties that arise in the tribal context).

15. See infra Part II.C (articulating contractor liability under the FTCA as applied to tribal contractors).

16. See, e.g., Henin v. Cancel, 708 F. Supp. 2d 1315, 1319 (S.D. Fla. 2010) (using the definition of federal law enforcement officer to effectively bar intentional tort claims against a tribal police officer).

17. In cases like Henin, where one of the FTCA's exceptions applies, the United States does not waive its sovereign immunity over the claim and the court has no jurisdiction to hear the matter. 708 F. Supp. 2d at 1318; see Dolan v. U.S. Postal Serv., 546 U.S. 481, 484-85 (2006) (discussing the requirements that must be met for a federal court to have jurisdiction over an FTCA claim). Therefore, there can be no recovery against the United States, which can only pay as directed by Congress. U.S. CONST. art. I, $\$ 9, \mathrm{cl}$. 7. Because the money paid out in FTCA suits ultimately comes from the public fisc, government attorneys should scrupulously attempt to apply the FTCA's exceptions. Paul Figley, Ethical Intersections $\mathcal{E}$ the Federal Tort Claims Act: An Approach for Government Attorneys, 8 U. ST. ThOMAs L.J. 347, 373-74 (2011).

18. See Trujillo v. United States, 313 F. Supp. 2d 1146, 1151 (D.N.M. 2003) (dismissing a suit against tribal police officers who were not federal law enforcement officers but noting that " $[u]$ nder different circumstances, the acts of [the tribal officers] might subject the United States to liability because of their status as federal employees"). 
recommends that Congress replace FTCA coverage with financial assistance to the tribes to obtain private insurance.

\section{BACKGROUND}

\section{A. Federal Tort Claims Act}

The FTCA provides a narrow waiver of the U.S. government's sovereign immunity. ${ }^{19}$ The doctrine of sovereign immunity provides that a sovereign state is immune to suit except for instances where the legislative branch takes action and consents to the suit. ${ }^{20}$ In practice, sovereign immunity means nobody can sue the United States, or a federal employee acting within the scope of his or her employment, unless Congress passes a statute waiving sovereign immunity. ${ }^{21}$ Before 1946, Congress did not systematically waive sovereign immunity for torts, and the chief recourse for those injured by torts committed by federal employees was to petition Congress for a private bill compensating the victim for the damages sustained. ${ }^{22}$ Having the legislature evaluating and settling tort claims created problems from the beginning. ${ }^{23}$ Over time, the congressional process for addressing these claims evolved; but at its best, the process was still woefully

19. United States v. Nordic Vill., Inc., 503 U.S. 30, 34 (1992) (observing the principle that the government's consent to suit must be strictly construed in favor of the sovereign and must not be enlarged beyond what the statutory language requires).

20. Paul Figley, A Guide to the Federal Tort Claims Act 5 (2012); see Gregory C. Sisk, The Inevitability of Federal Sovereign Immunity, 55 VILL. L. Rev. 899, 899 (2010) (observing that although the concept that the government can be excused from liability for some wrongs may seem troubling for many Americans, "few doctrines are more solidly anchored in Supreme Court precedent").

21. FIgLeY, supra note 20, at 5-6 (citing Lane v. Pena, 518 U.S. 187, 192 (1996)); see Nordic Vill., Inc., 503 U.S. at 33-34 (discussing the proper construction necessary for the government's waiver of sovereign immunity); Jaffee v. United States, 592 F.2d 712,717 \& n.10 (3d Cir. 1979) (analogizing the FTCA to "a traversable bridge across the moat of sovereign immunity").

22. FigLEY, supra note 20, at 6 (observing that the right to pursue damages when the government causes injury comes from the First Amendment); see U.S. CONST. amend. I ("Congress shall make no law ... abridging ... the right of the people ... to petition the Government for a redress of grievances.").

23. See Figley, supra note 20 , at $6 \& \mathrm{n} .9$ (tracing the history of the resolution of tort claims against the government and observing that Presidents John Quincy Adams and Abraham Lincoln expressed frustration with the cumbersome and inefficient congressional claims process); see also H.R. REP. No. 79-1287, at 1-2 (1945) (reporting on legislation to waive sovereign immunity and its motivating factors). 
inefficient. $^{24}$ Congress debated various proposals to address the problem, but it was not able to pass a comprehensive bill until $1946 .{ }^{25}$

The FTCA became law in 1946 and waived a considerable portion of the United States' sovereign immunity. ${ }^{26}$ The FTCA, however, does not waive all of the United States' sovereign immunity, and it still bars claims that do not meet the FTCA's requirements. ${ }^{27}$ The FTCA requires that claims be:

[1] against the United States, [2] for money damages, ... [3] for injury or loss of property, or personal injury or death [4] caused by the negligent or wrongful act or omission of any employee of the Government [5] while acting within the scope of his office or employment, [6] under circumstances where the United States, if a private person, would be liable to the claimant in accordance with the law of the place where the act or omission occurred. ${ }^{28}$

Sovereign immunity is jurisdictional in nature, and courts must first determine if the United States has waived its sovereign immunity with a statute like the FTCA before a case can proceed to the merits. ${ }^{29}$

The FTCA does not create a federal common law for torts and instead relies on the substantive state law of the place where the tort occurred. $^{30}$ Courts have almost universally interpreted the "law of the place" to be state law in FTCA suits. ${ }^{31}$ For FTCA purposes, federal

24. Congress created a Committee on Claims to handle tort claims against the government. FigLEY, supra note 20, at 7 . As the number of claims increased, the Committee's work became very onerous because of both the volume and complexity of the claims. Id.

25. See H.R. ReP. No. 77-2245 (1942) (reporting on an early incarnation of the FTCA); H.R. REP. No. 76-2428, at 1 (1940) (discussing waiving immunity with a liability cap at $\$ 7500$ ); FigLEY, supra note 20 , at 7 ; Gregory C. Sisk, The Continuing Drift of Federal Sovereign Immunity Jurisprudence, 50 WM. \& MARY L. REV. 517, 536 (2008) (noting that public outcry over a 1945 incident where a military plane struck the Empire State Building, killing ten people whose claims were barred by sovereign immunity, may have hastened passage of the FTCA, but was not the impetus for it, as Congress had been debating similar proposals for twenty years).

26. FigLeY, supra note 20, at 5-6.

27. Dolan v. U.S. Postal Serv., 546 U.S. 481, 485 (2006).

28. 28 U.S.C. $\$ 1346$ (b) (1) (2006); see FDIC v. Meyer, 510 U.S. 471, 477 (1994) (noting that a claim is only cognizable under the FTCA if it meets all six requirements in 28 U.S.C. $\$ 1346(\mathrm{~b})$ ).

29. See United States v. Mitchell, 463 U.S. 206, 212 (1983) ("It is axiomatic that the United States may not be sued without its consent and that the existence of consent is a prerequisite for jurisdiction.").

30. See Devlin v. United States, 352 F.3d 525, 532 (2d Cir. 2003) (“[T]he FTCA's basic thrust was decidedly not to create a federal common law of torts, but rather . . to tie the government's liability - albeit subject to a host of qualifications- to the disparate and always evolving tort law of the several states."); infra Part II.E (identifying choice-of-law problems that arise in FTCA cases involving tribal contractors).

31. See LaFromboise v. Leavitt, 439 F.3d 792, 794 (8th Cir. 2006) (observing that under the FTCA, state substantive tort law governs even when the incident occurred 
employees are generally defined to exclude contractors. ${ }^{32}$ The FTCA also contains important exceptions, including a bar on specified intentional torts. ${ }^{33}$ The FTCA's primary purpose is to give a remedy to those who had no recourse under the previous system of absolute sovereign immunity, not to provide an additional recourse to those who already had one elsewhere. ${ }^{34}$ An important theme in FTCA cases is that the FTCA is only a very limited waiver of the United States' sovereign immunity and that courts will strictly construe the FTCA's terms in favor of the sovereign. ${ }^{35}$

\section{B. Snyder Act}

Congress established the BIA in 1824 to provide services to the tribes. $^{36}$ The services the BIA provides cover a range of programs typically provided by state, federal, or local governments. ${ }^{37}$ The Snyder $\mathrm{Act}^{38}$ represents the first time Congress comprehensively addressed the services that the BIA provided to the tribes on Indian reservations. $^{39}$ By the end of World War I, Congress sought to

on land controlled by the federal government); see also infra Part II.E (arguing that courts should not apply tribal law in FTCA disputes).

32. See Logue v. United States, 412 U.S. 521, 531-32 (1973) (noting that simply carrying out a function that would otherwise have been performed by a federal employee is insufficient to make a contractor a federal employee for purposes of the FTCA); see also infra Part II.C (discussing the inconsistencies between the FTCA's general bar against contractor torts and Congress's decision to extend FTCA coverage to tribal contractors).

33. 28 U.S.C. $§ 2680(\mathrm{~h})$ (barring claims "arising out of assault, battery, false imprisonment, false arrest, malicious prosecution, abuse of process, libel, slander, misrepresentation, deceit, or interference with contract rights"); see infra II.D (reviewing issues that arise with torts committed by Indian law enforcement contractors)

34. See Feres v. United States, 340 U.S. 135, 140 (1950) (discussing the motivation behind the FTCA).

35. See Lane v. Pena, 518 U.S. 187, 192 (1996) (commenting that the waiver of the United States' sovereign immunity must be unequivocally expressed and cannot be implied); see also Kosak v. United States, 465 U.S. 848, 853 n.9 (1984) (providing that a court's goal in interpreting the FTCA is "to identify "those circumstances which are within the words and reason of the exception'- no less and no more" (quoting Dalehite v. United States, 346 U.S. 15, 31 (1953))).

36. Who We Are, BUREAU OF INDiAn AFFAIRS, http://www.bia.gov/WhoWeAre/ index.htm (last updated Nov. 5, 2012, 4:35 PM).

37. See What We Do, BurEau OF InDian AfFaIRS, http:/ /www.bia.gov/WhatWeDo/ index.htm (last updated Nov. 5, 2012, 4:35 PM) (mentioning education, natural resources management, law enforcement, social services, and economic development as some of the services provided).

38. Ch. 115, 42 Stat. 208 (1921) (codified as amended at 25 U.S.C. $\$ 13$ (2006)).

39. See Morton v. Ruiz, 415 U.S. 199, 205-06 (1974) (noting that before the Snyder Act, there was no general congressional authorization for BIA activities); see also S. REP. No. 67-294, at 1 (1921) (observing that there was "no basic law at the present time authorizing many of the items appearing in the annual Indian appropriation act"). The Snyder Act authorizes the BIA to "expend such moneys as Congress may from time to time appropriate, for the benefit, care, and assistance of 
consolidate the unwieldy budgetary process. ${ }^{40}$ During the nineteenth century, Congress had assigned jurisdiction over certain appropriations bills to committees other than the appropriations committees. ${ }^{41} \quad$ These committees, including the Indian Affairs Committee, considered their own appropriations without needing separate authorizing legislation. ${ }^{42}$ In response, Congress passed the Budget and Accounting Act of $1921^{43}$ to consolidate appropriations jurisdiction solely under the appropriations committees in the House and Senate. ${ }^{44}$ Under the revised appropriations system, Indian appropriations received greater scrutiny on the House floor, which resulted in many of them being struck down on points of order because they lacked proper legislative authorization. ${ }^{45}$ The Snyder Act remedied this situation by providing general authorization of subsequent Indian bills, including annual budget appropriations for the BIA. ${ }^{46}$

The Snyder Act does not enlarge the mandate of the BIA and was only intended to authorize services that the BIA already provided to the tribes. ${ }^{47}$ Additionally, the Act does not provide a private damages remedy. ${ }^{48}$ The Snyder Act demonstrates Congress's reactive approach to Indian law in that it belatedly provided blanket authorization to

the Indians throughout the United States for . . the employment of inspectors, supervisors, superintendents, clerks, field matrons, farmers, physicians, Indian police, Indian judges, and other employees.” 25 U.S.C. $\$ 13$ (2006).

40. Jessica TOllestrup, CONG. RESEARCH SERV., RL 31572, Appropriations Subcommittee Structure: History of Changes From 1920-2011, at 1-2 (2011) (detailing the congressional concerns regarding the unwieldy nature of the jurisdiction and topical focus of most congressional appropriations committees).

41. See id. (recounting that the District of Columbia, Indian Affairs, Agriculture Department, Army, Navy, and Post Office committees all considered their own appropriations, unlike the current system where all appropriations are handled through a centralized appropriations committee in both the House and the Senate).

42. See id. at 2 (describing the piecemeal appropriations process of the early twentieth century).

43. Ch. 18, 42 Stat. 20 (codified as amended at 31 U.S.C. 703 (2006)).

44. TOLLESTRUP, supra note 40, at 1 .

45. See Morton v. Ruiz, 415 U.S. 199, 206 (1974) (tracing the history of the Snyder Act and concluding that its primary purpose was procedural).

46. Id.; COHEN's HANDBOOK OF FEDERAL INDIAN LAW § 22.01[1], at 1339 (Nell Jessup Newton et al. eds., 2005).

47. H.R. REP. NO. 67-275, at 1 (1921); S. REP. No. 67-294, at 1 (1921); see Lincoln v. Vigil, 508 U.S. 182, 194 (1993) (concluding that the Snyder Act creates no new binding obligations on the federal government).

48. See Samish Indian Nation v. United States, 419 F.3d 1355, 1366 (Fed. Cir. 2005) (noting that because the Snyder Act did not obligate the federal government to expend any funds in Indian country, failure to do so would not support a damages remedy). 
programs that had been in existence for years. ${ }^{49}$ Although today the Snyder Act is largely a historical footnote, for almost fifty years, until the passage of the Self-Determination Act, it provided broad congressional authorization for BIA activity carried out in Indian country. ${ }^{50}$

\section{Indian Self-Determination Act}

After many years of providing services to the tribes, the federal government began implementing a policy of tribal self-determination in the 1970 s. $^{51}$ Congress initially passed the Self-Determination Act in 1974 to promote tribal self-government. ${ }^{52}$ The Senate Committee on Interior Affairs noted that the passage of this bill showed how federal Indian policy had shifted dramatically towards the Indian tribes taking over the provision of services formerly administered by the BIA and the Indian Health Service (IHS) ${ }^{53}$ Instead of relying too heavily on an exceptionally broad reading of the Snyder Act, Congress passed the Self-Determination Act, which specifically authorized these new policies emphasizing tribal self-determination and detailing how the contracts are to be arranged. ${ }^{54}$ With the SelfDetermination Act, Congress facilitated a program wherein the Indian tribes can contract directly with the BIA to take over the provision of services in Indian country. ${ }^{55}$ As originally passed, the Self-Determination Act allowed the Secretary of the Interior to require the tribes to purchase insurance to cover any liability they

49. See 61 Cong. Rec. 6529 (1921) (statement of Sen. Charles Curtis) (commenting that the Snyder Act covers activities the BIA has been undertaking for thirty years).

50. See S. ReP. No. 93-682, at 13 (1974) (suggesting that BIA activity in Indian country relied on a strained reading of old statutes that were not meant to address the kinds of activity that the BIA was actually carrying out).

51. See Special Message to the Congress on Indian Affairs, Pub. PAPERs 564, 566 (July 8, 1970) ("[Self-Determination], then, must be the goal of any new national policy toward the Indian people: to strengthen the Indian's sense of autonomy without threatening his sense of community.").

52. See 25 U.S.C. \$ 450a(a) (2006) (stating that the goal of the SelfDetermination Act is to encourage "maximum Indian participation"); S. REP. No. 93682, at 12-13 (1974) (tracing the history of the tribes' relationship with the federal government and noting the shift from having the government directly providing services to the tribes to having the tribes take over these services by contract).

53. See S. REP. No. 93-682, at 13 (noting that the shift in policy towards selfdetermination is dramatic).

54. See id. ("The difficulties in straining statutory language beyond its original intent creates numerous administrative and management problems which [the SelfDetermination Act] is designed to correct."); see also supra note 46 and accompanying text (discussing Congress's reasons for passing the Snyder Act).

55. See S. REP. No. 93-682, at 15 (noting that the Self-Determination Act provides authority for the BIA to contract with the tribes, but does not require them to do so). 
incurred while carrying out the activities they had contracted to take over from the BIA. ${ }^{56}$

The transition to self-determination, however, was not seamless. One problem Congress identified was that the cost of acquiring liability insurance was a barrier to the tribes entering into selfdetermination contracts. ${ }^{57}$ Because the BIA is part of the federal government, the FTCA delineates liability for it and its agents in tort suits, and the BIA would never have needed to purchase additional insurance to carry out the services that the tribes were assuming. ${ }^{58}$ As a result, in 1988 Congress amended the Self-Determination Act, seeking to remove barriers to additional tribal contracting. ${ }^{59}$ The 1988 Self-Determination Act amendments required the Secretary of the Interior, who oversees the BIA, to help the tribes acquire costeffective insurance so that more tribes could enter into SelfDetermination Act contracts. ${ }^{60}$

Congress, however, did not wait for the Secretary of the Interior to promulgate regulations on private insurance for tribal contractors. Instead, Congress included language in the 1991 Department of the Interior Appropriations Bill that extended FTCA protection to tribal contractors working pursuant to a Self-Determination Act contract. ${ }^{61}$

56. Self-Determination Act, Pub. L. No. 93-638, § 102(c), 88 Stat. 2203, 2206 (1975). See generally U.S. GEN. AcCOUnTING OfFICE, GAO/RCED-00-169, FEDERAL Tort Claims Act: Issues Affecting Coverage for Tribal Self-Determination CONTRACTS 25 fig.5 (2000) [hereinafter 2000 GAO REPORT] (depicting the early history of the Self-Determination Act provisions and subsequent amendments in graphic form).

57. See Salazar v. Ramah Navajo Chapter, 132 S. Ct. 2181, 2186 (2012) (noting that the Self-Determination Act originally provided for only the direct administrative costs of the programs, which "failed to account for the full costs to tribes of providing services"); Indian Self-Determination and Education Assistance Act Amendments of 1987-Part II: Hearing on S. 1703 Before the S. Select Comm. on Indian Affairs, 100th Cong. 54 (1987) [hereinafter 1987 Senate Self-Determination Act Hearing] (testimony of William Ron Allen, Chairman, Jamestown Klallam Tribe) (suggesting that insurance is a major indirect cost that the tribes incur when entering into a Self-Determination Act contract with the BIA); see also Letter from John R. Bolton, Assistant Att'y Gen., to Sen. Daniel K. Inouye (Oct. 27, 1987), reprinted in S. REP. No. 100-274, at 59-60 (1987) (warning that the possibility of using the FTCA to insure tribal contractors violates the principle of not extending the FTCA to government contractors and suggesting that other contractors will seek such coverage).

58. See H.R. ReP. No. 100-393, at 4 (1987) (finding that because the tribes have to pay certain extra costs to provide the services that the government does not cover, some tribes feel they are being charged a penalty for the right to contract).

59. Indian Self-Determination and Education Assistance Act Amendments of 1988, Pub. L. No. 100-472, 102 Stat 2285 (codified as amended in scattered sections of 25 U.S.C.).

60. 25 U.S.C. $\$ 450 \mathrm{f}(\mathrm{c})(2006)$.

61. Department of the Interior and Related Agencies Appropriations Act, 1991, Pub. L. No. 101-512, § 314, 104 Stat 1915, 1959-60 (1990). 
The bill stated:

[Any] Indian tribe, tribal organization or Indian contractor ... and its employees are deemed employees of the [U.S. government] while acting within the scope of their employment in carrying out the contract or agreement .... [A] ny civil action or proceeding involving such claims brought hereafter against any tribe, tribal organization, Indian contractor or tribal employee covered by this provision shall be deemed to be an action against the United States... and be afforded the full protection and coverage of the Federal Tort Claims Act. ${ }^{62}$

Legislative history on this provision is scant, but upon signing the bill, President George H.W. Bush expressed "serious reservations" about extending the FTCA to cover tribal contractors. ${ }^{63}$ President Bush explained that the bill extending FTCA coverage to tribal contractors was "fundamentally flawed" because the United States does not supervise tribal contractors the way it would supervise traditional employees, and to do so would be counterproductive to the goal of Indian self-determination. ${ }^{64}$

Congress amended the Self-Determination Act again in 1994, attempting to provide clarity by formally directing the Secretary of the Interior to promulgate regulations on how the FTCA related to the Self-Determination Act. ${ }^{65}$ The regulations promulgated after the 1994 amendments give some basic guidance and specify that Congress extended FTCA protection to the Indian tribes contracting under the Self-Determination Act regardless of whether the funding agreement specifically mentions this coverage as a term. ${ }^{66}$ Furthermore, the regulation notes that the FTCA is the exclusive remedy for tort claims resulting from Self-Determination Act contracts. $^{67}$ Only programs previously administered by the BIA are

62. Id.

63. Statement on Signing Department of the Interior and Related Agencies Appropriations Act, 1991, 2 PUB. PAPERS 1558 (Nov. 5, 1990).

64. Id. at 1559; see also infra Part II.C (arguing that classifying Indian contractors as federal employers contravenes FTCA jurisprudence regarding contractors).

65. Indian Self-Determination Contract Reform Act of 1994, Pub. L. No. 103-413, $\S 105,108$ Stat 4250, 4269 (codified as amended at 25 U.S.C. $\$ 450 \mathrm{k}(2006)$ ); see 140 CONG. REC. 18,389 (1994) (statement of Rep. Bill Richardson) ("The regulatory process has cost the tribes hundreds of thousands of dollars, and has led to great confusion within Indian country and among the Federal agencies.").

66. 25 C.F.R. $\$ 1000.276$ (2012).

67. Id. $\$ 1000.279$. But see Christie, supra note 10 , at 124 (observing that at least one tribal court has decided that it remains responsible for certain cases). Tribal members can still bring claims against tribal corporations in tribal court. E.g., Wide Ruins Cmty. Sch., Inc. v. Stago, 281 F. Supp. 2d 1086, 1088-90 (D. Ariz. 2003) (recognizing only cognizable claims under the FTCA in federal court, but noting that these proceedings did not bar tribal members from bringing additional claims under tribal law in Navajo court). 
eligible for Self-Determination Act contracts. ${ }^{68}$ Congress has made additional, minor amendments to the Self-Determination Act, but none have changed the application of the FTCA to tribal contractors. $^{69}$ Despite the regulations, many questions remain unanswered as to the precise mechanics of applying the FTCA to tribal contractors, and subsequent decisions have created more uncertainty for the government and the tribes. ${ }^{70}$

\section{Indian Law Enforcement Reform Act}

Many Indian reservations grapple with crime rates worse than those in some of the country's most violent cities. ${ }^{71}$ Violent crime rates on Indian reservations are more than twice the national average. ${ }^{72}$ As such, law enforcement is a particularly significant BIA function that the tribes contract for under the Self-Determination Act. ${ }^{73}$ When Congress began to consider challenges in tribal law enforcement, the BIA already employed approximately 500 law enforcement officers, and the tribes employed 900 more officers. ${ }^{74}$ Typical tribal police departments tend to be woefully understaffed, with only a few officers patrolling huge rural areas. ${ }^{75}$ In 1990, Congress passed the Indian

68. See 25 C.F.R. $\$ 1000.86$ (noting that the BIA need not have provided that particular service to that particular tribe in order to enter a Self-Determination Act contract, as long as the BIA did provide that service to a tribe). Regulations also allow for limited contracting of non-BIA programs that are designated by the Secretary of the Interior or have "special geographic, historical or cultural" significance to the tribes. Id. $\$ \S 1000.120-.148$. Nevertheless, some tribes still find it very difficult to enter into contracts with the BIA, although there are no reported cases where FTCA coverage was not extended to tribal contractors on the ground that the function they contracted for had not previously been performed by the BIA. See The Success and Shortfall of Self-Governance Under the Indian Self-Determination and Education Assistance Act After Twenty Years: Hearing Before the S. Comm. on Indian Affairs, 110th Cong. 54 (2008) [hereinafter 2008 Senate Self-Determination Act Hearing] (statement of James Steele, Jr., Tribal Council Chairman, Confederated Salish and Kootenai Tribes) (discussing the difficulties of contracting for non-BIA programs and suggesting that in the instances when the tribes are able to do so, they should get FTCA coverage).

69. See Tribal Self-Governance Amendments of 2000, Pub. L. No. 106-260, 114 Stat. 711 (codified at 25 U.S.C. $\$ \$ 458$ aaa-1 to 458 aaa-18 (2006)).

70. See infra Part II (explaining some of the problems with applying the FTCA to tribal contractors).

71. See Timothy Williams, Higher Crime, Fewer Charges on Indian Land, N.Y. Times, (Feb. 20, 2012), http://www.nytimes.com/2012/02/21/us/on-indian-reservationshigher-crime-and-fewer-prosecutions.html (suggesting that failure to effectively prosecute the crimes may be exacerbating the problem).

72. Id.

73. See S. REP. No. 101-167, at 5 (1989) (noting the prevalence of tribal law enforcement being operated under Self-Determination Act contracts).

74. Id.

75. See Bertagna, supra note 11, at 600-01 (contending that one to three officers may be in charge of policing an area roughly the size of the entire state of Delaware). 
Law Enforcement Reform Act ${ }^{76}$ (ILERA) to "clarify and strengthen the authority" for law enforcement in Indian country. ${ }^{77}$ ILERA gave explicit statutory authority to the BIA for its law enforcement activities in Indian country to avoid a potentially embarrassing situation where a court found a BIA officer personally liable for carrying a firearm and making arrests without authorization. ${ }^{78}$ The bill also facilitated cooperation among BIA law enforcement and tribal law enforcement, including provision for cross-deputation agreements. $^{79}$ Prior to the bill, Indian law enforcement rested on shaky statutory ground, justified only by the Snyder Act and various Indian liquor control laws. ${ }^{80}$ Congress passed ILERA because it feared judicial challenges to BIA officers and Indian contractors carrying out law enforcement duties in Indian country. ${ }^{81}$ In addition, Congress passed the Tribal Law and Order Act of 2010, ${ }^{82}$ which further clarifies the law enforcement authority of the tribes but does not affect FTCA liability. ${ }^{83}$

\section{E. Congressional Proposals for Reform}

Using the FTCA to cover tribal contractors created a host of problems in theory and in practice. Congress has tried to address some of these problems, but has stopped short of passing any major reforms. In 1998, Senator Slade Gorton of Washington introduced the American Indian Equal Justice Act to address the relationship between sovereign immunity and the Indian tribes. ${ }^{84}$ The bill sought to make tribal governments liable in certain civil matters. ${ }^{85}$ Senator

76. Pub. L. No. 101-379, §§ 1-11 104 Stat. 473, 473-78 (1990) (codified at 25 U.S.C. $\$ \S 2801-2809(2006))$.

77. 135 CONG. Rec. 10,029 (1989) (statement of Rep. George Miller).

78. H.R. REP. NO. 101-60, at 4-5 (1989).

79. Id.

80. See S. ReP. No. 101-167, at 5 (expressing concern that BIA officers did not have explicit statutory authority to exercise their law enforcement duties).

81. See id. (indicating that the proposed bill was intended to "avoid a successful judicial challenge" to BIA authority by providing "comprehensive statutory authority"); H.R. REP. NO. 101-60, at 4-5 (1989) (mirroring the concerns in the Senate committee report); see also Dry v. United States, 235 F.3d 1249, 1252-59 (10th Cir. 2000) (illustrating the complexities that arise in tribal law enforcement, even after ILERA, in a case involving tribal law enforcement, federal law enforcement, and claims under the FTCA, Bivens, and § 1983); infra Part II.B.2 (discussing the potential for problems that arise from the definition of Indian country and its uncertain boundaries in some parts of the country).

82. Pub. L. No. 111-211, §§ 201-266, 124 Stat 2258, 2261-2301 (codified in scattered titles of the U.S. Code).

83. E.g., 25 U.S.C. § 2812 (Supp. IV 2011) (establishing the Indian Law and Order Commission).

84. S. 1691, 105th Cong. (1998).

85. Id. §1(c). 
Gorton intended his proposal to parallel the Tucker Act ${ }^{86}$ and to strip the tribes of sovereign immunity almost entirely. ${ }^{87}$ The Gorton bill gave federal courts jurisdiction over civil actions against the Indian tribes for injury caused by the negligence of the tribes under circumstances where the tribe would be liable if it were a private person or corporation. ${ }^{88}$ The Gorton bill would have effectively stripped the tribes of their FTCA coverage and shifted the cost of insuring Self-Determination Act contractors back to the tribes. ${ }^{89}$ One major consequence of the Gorton bill for tort suits would have been that the tribes would no longer have been able to take advantage of the FTCA's sweeping protection for discretionary functions and the procedural protections of an administrative claims process. ${ }^{90}$ Critics of the Gorton bill suggested that taking the FTCA's protections away from tribal contractors unfairly treated the tribes as contractors

86. 28 U.S.C. $\$ 1491$ (waiving sovereign immunity for claims involving contracts).

87. S. $1691 \S 4(\mathrm{a}) ; c f$. Washington v. Confederated Bands \& Tribes of the Yakima Indian Nation, 439 U.S. 463, 501 (1979) ("It is well established that Congress, in the exercise of its plenary power over Indian affairs, may restrict the retained sovereign powers of the Indian tribes.").

88. S. 1691, § 4(a).

89. Thomas P. Schlosser, Sovereign Immunity: Should the Sovereign Control the Purse?, 24 AM. INDIAN L. REV. 309, 337-38 (2000) (arguing that " [t] here is no obvious policy justification" for removing FTCA coverage from tribal contractors). As a general rule, "an Indian tribe is subject to suit only where Congress has authorized the suit or the tribe has waived its immunity." Kiowa Tribe of Okla. v. Mfg. Techs., Inc., 523 U.S. 751, 754 (1998). The Gorton bill would have removed more tribal sovereign immunity than would be necessary to pursue tort claims against tribal contractors. See Schlosser, supra, at 339 (noting that the Gorton proposal would waive sovereign immunity but would not provide any defenses like the FTCA does). The Gorton bill would require the tribes to purchase private insurance like they did in the past. S. 1691, § 4; see supra notes 56-62 and accompanying text (illustrating that before 1990, the tribes could not assert federal sovereign immunity to bar claims against tribal contractors and had to purchase private insurance).

90. Schlosser, supra note 89, at 339. See generally FigLEY, supra note 20, at 47-48 (explaining the administrative claims process in detail). The discretionary function exception to the FTCA protects the United States from liability where a federal employee's actions involve an element of judgment or choice and those actions are based on considerations of public policy. See Berkovitz v. United States, 486 U.S. 531, 536-37 (1988) (establishing the often-cited test for determining whether actions fall within the FTCA's discretionary function exception); infra Part II.A.2 (discussing the inherent difficulties courts face in applying the FTCA's discretionary function exception to tribal contractors). 
rather than as sovereign nations. ${ }^{91}$ Congress never adopted Senator Gorton's bill. ${ }^{92}$

In the same year, Senator Ben Nighthorse Campbell of Colorado, himself a Native American, ${ }^{93}$ introduced the Indian Tribal Conflict Resolution and Tort Claims and Risk Management Act of 1998, which took a different approach to addressing issues relating to liability coverage for tribal contractors. ${ }^{94}$ Unlike the Gorton bill, the Campbell bill did not take any sovereign immunity away from the tribes and dealt only with delineating what would be covered by the FTCA and what would be covered by private insurance. ${ }^{95}$ The Campbell bill aimed to provide tort victims with a remedy in instances that were not covered by the FTCA. $^{96}$ The Campbell bill required the BIA to obtain insurance coverage for functions not covered by the FTCA and to provide yearly updates to Congress. ${ }^{97}$ Congress never passed the Campbell bill directly, but portions of the bill requiring the Secretary to study tort liability issues relating to tribal contractors passed as part of an omnibus appropriations bill. ${ }^{98}$ The Secretary of the Interior was unable to complete the required liability study on time..$^{99}$ Ultimately, the Campbell bill resulted in a 2000 Government Accounting Office ${ }^{100}$ (GAO) report and also a

91. See Sovereign Immunity: Hearing Before the S. Comm. on Indian Affairs, 105th Cong. 3 (1998) [hereinafter 1998 Senate Tribal Sovereign Immunity Hearing] (statement of Sen. Daniel K. Inouye, Vice Chairman, S. Comm. on Indian Affairs) (suggesting that the Gorton bill would overturn years of precedent and relegate the tribes from government status to private person or corporate status); Schlosser, supra note 89, at 339 (arguing that the Gorton bill did not treat the tribes as fairly as the federal and state governments did).

92. See Schlosser, supra note 89, at 355 (describing the Gorton proposal as a "legislative attack[]" on tribal sovereign immunity but noting that it failed).

93. Jody Hope Strogoff \& Ernest Luning, InnerView with Ben Nighthorse Campbell, COLO. STATESMAN (Mar. 25, 2011), http:/ / www.coloradostatesman.com/content/ 992685-innerview-ben-nighthorse-campbell.

94. S. 2097, 105th Cong. (1998).

95. Compare S. $2097 \S 201$ (b) (requiring better coordination between the tribes and the United States to avoid duplicative costs), with American Indian Equal Justice Act, S. 1691, 105th Cong. $\$ 4$ (1998) (abrogating tribal sovereign immunity completely).

96. See 105 Cong. Rec. 9867 (1998) (statement of Sen. Ben Nighthorse Campbell) (noting that the tribes already have insurance and that there is a possibility of redundancy with FTCA coverage).

97. S. $2097 \S \S 201(\mathrm{~b})(1), 202(\mathrm{~b})$. This insurance policy must contain a provision that the insurance carrier will not invoke tribal sovereign immunity as a defense. Id. $\S 201(\mathrm{c})(1)$.

98. Indian Tribal Tort Claims and Risk Management Act of 1998, Pub. L. No. 105-277, § 704, 112 Stat. 2681, 2681-336.

99. See Schlosser, supra note 89, at 348 (disparaging the Interior Secretary's failure to produce a report by its 1999 deadline).

100. The GAO is now called the Government Accountability Office. See GAO Human Capital Reform Act of 2004, Pub. L. 108-271, § 8(a), 118 Stat. 811, 814. 
report from the BIA, which the agencies presented to Congress in a hearing before the Senate Committee on Indian Affairs. ${ }^{101}$

The BIA report concluded that the tribes find FTCA coverage to be limited and overly complex. ${ }^{102}$ The BIA found that even under the most expansive reading, the FTCA would not cover all tribal contractor activities. ${ }^{103}$ Therefore, the tribes still carry liability insurance to protect themselves from liability incurred in the course of carrying out Self-Determination Act contracts, even though this cost was precisely what Congress sought to eliminate. ${ }^{104}$ The BIA report recommended that Congress pass additional legislation to provide guidance on some of the issues that have arisen in applying the FTCA to tribal contractors. ${ }^{105}$

The GAO report identified many of the issues discussed in Part II of this Comment as problematic, including choice of law, the status of tribal law enforcement, and the scope of employment determinations. ${ }^{106}$ The report also suggested a procedural problem-that the current statutory scheme lacks a removal procedure for claims against tribal contractors filed in tribal courts. ${ }^{107}$ The report observed: "Given the tribes' historical liability for selfdetermination programs prior to 1990, their current liability for their non-self-determination programs, and the complexity and uncertainty of FTCA coverage, it is understandable why some tribes may choose to have comprehensive private liability insurance that covers all their programs." 108 The GAO report concluded that the government should receive the benefit of those private insurance policies and recommended that the Secretary of the Interior check the status of a tribe's insurance policy before proceeding with a claim under the FTCA. ${ }^{109}$ The report suggested that when the tribes have

101. See GAO and BIA Reports on Risk Management and Tort Liability: Hearing Before the S. Comm. on Indian Affairs, 106th Cong. 97 (2000) [hereinafter 2000 Senate Tribal Tort Liability Hearing] (report from the BIA) (revealing the poor response from the tribes and the likely futility of continued annual reports).

102. Id. at 96 .

103. Id.

104. Id:; see 1987 Senate Self-Determination Act Hearing, supra note 57, at 54 (testimony of William Ron Allen, Chairman, Jamestown Klallam Tribe) (describing how paying for insurance creates a major barrier to entering into Self-Determination Act contracts and diverts funds needed to carry them out).

105. See 2000 Senate Tribal Tort Liability Hearing, supra note 101, at 87-88 (characterizing the issues created by covering tribal contractors with the FTCA as "[u]nique").

106. 2000 GAO REPORT, supra note 56, at 17-18.

107. Id. at 15; see id. at 31 fig.6 (illustrating how the FTCA is "not a perfect fit" for tribal contractors because it leaves considerable gaps).

108. Id. at 18.

109. Id. at 18-19. 
private insurance that is duplicative with the FTCA, the Secretary of the Interior should tender the claims to private insurance companies. ${ }^{110}$ Despite the hearing, Congress ultimately declined to pursue legislative changes. ${ }^{11}$

Over the years, Congress has addressed issues of Indian selfdetermination in a piecemeal way. Although it has certainly touched on some key issues and focused on them for brief periods of time, it has failed to adequately assess the ramifications of extending the FTCA to tribal contractors. Using the FTCA rather than private insurance to protect contractors from liability was a major policy change haphazardly included in an appropriations bill. The courts, the tribes, and the government have been struggling to reach a workable solution.

\section{EXTENDING THE FTCA TO CLAIMS AGAINST TRIBAL CONTRACTORS Is A POOR FIT}

Courts had established a body of FTCA jurisprudence for over forty years before it was hastily extended to cover tribal contractors. The past twenty years have shown that using the FTCA to cover tribal contractors has turned out to be the proverbial square peg being forced into the round hole. This section examines the specific problems Congress created by using the FTCA in this way. First, this section addresses the theoretical issues behind sovereign immunity and the FTCA's discretionary function protection, exploring the bizarre dynamics of having the terms of a waiver of one sovereign's immunity protect another sovereign. Second, this section discusses issues involved in establishing that a federal employee is within the scope of his or her employment for FTCA purposes and the difficulties created by applying this body of law to the tribes. Third, this section analyzes the FTCA's strict exclusion of contractors and establishes that the tribes are unlike any other exceptions Congress or courts have made. Fourth, this section looks at Indian law enforcement and steps that some courts have taken to avoid federal liability when tribal officers commit torts. Finally, this section discusses the web of choice-of-law issues raised by the current

110. Id. at 19 (suggesting that the Secretary should only tender claims to private insurers when it is in the best interest of the United States).

111. 2000 Senate Tribal Tort Liability Hearing, supra note 101, at 1-2 (statement of Sen. Ben Nighthorse Campbell, Chairman, S. Comm. on Indian Affairs); see Tribal Self-Governance Amendments of 2000, Pub. L. No. 106-260, 114 Stat. 711 (amending the Self-Determination Act without addressing private insurance). 
arrangement and argues that state law rather than tribal law should always be used to govern FTCA suits.

A. Sovereign Immunity: Extending the FTCA to Tribal Contractors Contravenes the Principles of Sovereign Immunity by Having a Waiver of One Sovereign's Immunity Protect Another Sovereign

The FTCA is a waiver of the federal government's sovereign immunity. The tribes, however, have their own sovereign immunity. Using the FTCA to cover tribal contractors creates a bizarre situation where a waiver of one sovereign's immunity is being applied to another sovereign. This section will first discuss the theoretical problems of that arrangement. In addition, a key provision of the FTCA does not waive federal sovereign immunity for discretionary functions. Having this sweeping protection apply to the tribes makes it difficult for courts to reconcile these cases with years of discretionary function jurisprudence. The second part of this section discusses the difficulties that the current arrangement creates in applying the FTCA's discretionary function exception.

\section{Theoretical problems}

The current statutory scheme that governs tribal contractors is hard to reconcile with the principles that led Congress to pass the FTCA. Specifically, the FTCA is based on the principles of sovereign immunity and the idea that the United States can only be sued when it consents. ${ }^{112}$ Courts treat the Indian tribes as "domestic dependent nations" $" 113$ that possess their own tribal sovereign immunity. ${ }^{114}$ The Supreme Court noted that Congress has abrogated tribal immunity through certain laws, such as the Self-Determination Act, which authorize limited classes of suits against the tribes. ${ }^{115}$ The current statutory arrangement uses a waiver of the United States' sovereign

112. FDIC v. Meyer, 510 U.S. 471, 475-76 (1994).

113. See Cherokee Nation v. Georgia, 30 U.S. (5 Pet.) 1, 17-18 (1831) (describing the relationship between the United States and the Indian tribes as "peculiar"). See generally Sarah Krakoff, Undoing Indian Law One Case at a Time: Judicial Minimalism and Tribal Sovereignty, 50 AM. U. L. REv. 1177, 1193-96 (2001) (discussing the early development of Indian law in the Supreme Court and the Marshall Court's recognition of the tribes as "pre-constitutional sovereigns").

114. See, e.g., Okla. Tax Comm'n v. Citizen Band Potawatomi Indian Tribe, 498 U.S. 505, 509 (1991) (explaining that the tribes have their own tribal sovereign immunity and cannot be sued absent a "clear waiver by the tribe or congressional abrogation").

115. See id. at 510 (observing that although Congress has always been free to waive tribal sovereign immunity and has done so for limited classes of suits, it had not done so for tax assessment actions like the one brought by Oklahoma against the Potawatomi Indians). 
immunity - the FTCA - to protect the tribes from liability, even though the tribes are different sovereigns with their own sovereign immunity. ${ }^{116}$

Tort law creates incentives for potential defendants to act more carefully to avoid lawsuits. ${ }^{117}$ Extending FTCA coverage to the tribes does not create these incentives for tribal contractors because the United States, rather than the tribes, actually pays the judgments. ${ }^{118}$ Rather, the current arrangement creates a perverse system of incentives for tribal contractors not to cooperate with investigations, particularly when the tort victim is also a tribal member. ${ }^{119}$ Lack of

116. See Santa Clara Pueblo v. Martinez, 436 U.S. 49, 58 (1978) ("Indian tribes have long been recognized as possessing the common-law immunity from suit traditionally enjoyed by sovereign powers."); see also 25 U.S.C. § 450f(c) (2006) (waiving the defense of tribal sovereign immunity for Self-Determination Act contracts); Walton v. Tesuque Pueblo, 443 F.3d 1274, 1280 (10th Cir. 2006) (recognizing that the Self-Determination Act waives tribal sovereign immunity, although not in the instant case, because the plaintiff was not a party to a SelfDetermination Act contract). The FTCA waives the federal government's immunity for tort suits but provides a number of exceptions that are used as defenses. Meyer, 510 U.S. at 475 . Under the current arrangement, tribal employees are able to take advantage of FTCA exceptions originally designed to protect the federal government. See, e.g., Hinsley v. Standing Rock Child Protective Servs., 516 F.3d 668, 672 (8th Cir. 2008) (using the FTCA's discretionary function exception to protect a tribal social services agency from a negligence claim where it placed a child with a history of sexually abusing others in a foster home with no warning to the new foster parents).

117. See United States v. Carroll Towing Co., 159 F.2d 169, 173 (2d Cir. 1947) ("[I]f the probability be called P; the injury, L; and the burden, B; liability depends upon whether B is less than L multiplied by P: i.e., whether B $<$ PL."); VICTOR E. Schwartz ET AL., Prosser, Wade and Schwartz's Torts: Cases and Materials 1 (12th ed. 2010) (identifying deterrence of wrongful conduct and encouragement of socially responsible behavior as two of the major purposes of tort law); Jonathan Turley, Pax Militaris: The Feres Doctrine and the Retention of Sovereign Immunity in the Military System of Governance, 71 GEO. WASH. L. REV. 1, 47 (2003) (observing that there is "little question" that increasing liability will influence a rational actor's conduct). But see Paul Figley, In Defense of Feres: An Unfairly Maligned Opinion, 60 AM. U. L. Rev. 393, 463-64 (2010) (asserting that government agencies are not responsive to financial deterrence because they do not pay FTCA settlements in excess of \$2500).

118. See FigLEY, supra note 20, at 76-77 (noting that all FTCA judgments against the government are paid out of the Judgment Fund). Because the tribes would have no financial consequences for their torts there would be little incentive to act more carefully. See Letter from John R. Bolton, Assistant Att'y Gen., to Sen. Daniel K. Inouye, supra note 57, at 60 ("To relieve contractors from responsibility for their conduct without being able to control that conduct completely defeats the deterrent value of the fault-based tort compensation system.").

119. See 2000 GAO REPORT, supra note 56, at 19 (noting that the federal government is ultimately liable for FTCA claims, and that some contractors refused to cooperate with investigations); Letter from Edward B. Cohen, Acting Solicitor, U.S. Dep't of the Interior, to Jim Wells, Director, Energy, Resources, and Science Issues, U.S. Gen. Accounting Office at 2 (July 20, 2000), in 2000 GAO REPORT, supra note 56, at 37 (observing a lack of incentives for loss reduction among tribal contractors and occasional uncooperativeness from the tribes and their contractors). There is no way to know whether the tribes cooperated in specific reported cases, although presumably it would be difficult for the United States to go to trial without 
cooperation makes it difficult for the United States to assert a vigorous defense and could increase the amount of settlements and judgments paid. ${ }^{120}$

Furthermore, even though the tribes receive FTCA coverage, they often carry private liability insurance too, which in some instances is paid for with federal contract support funds and provides duplicative coverage with the FTCA. ${ }^{121}$ There is currently no mechanism in place to determine where this private coverage overlaps with liability that is covered by the FTCA. ${ }^{122}$ Because the government pays out FTCA judgments virtually automatically through the Judgment Fund, plaintiffs may choose to pursue an FTCA claim rather than a claim against the insurance company. ${ }^{123}$

In addition, the insurance companies get paid for policies, portions of which would likely never be triggered because these provisions are duplicative with FTCA coverage and have little incentive to make the system more efficient. ${ }^{124}$ Rather than streamlining the process of insuring tribal contractors, Congress has created a system full of perverse incentives and duplicative costs that conflicts with the principles on which the FTCA is based.

tribal cooperation. See, e.g., Challinor v. United States, No. CV-11-3099-EFS, 2012 WL 523673, at*1 (E.D. Wash. Feb. 15, 2012) (commenting that it was unclear whether the tribal contractor had investigated the accident and suggesting that the tribe blocked Occupational Safety and Health Agency access to the accident site, compromising the investigation).

120. See, e.g., Challinor, 2012 WL 523673, at *1 (discussing how a tribe's lack of cooperation undermined the government's investigation); cf. 2000 GAO REPORT, supra note 56, at 19-20 (suggesting that instances of lack of cooperation appear to be isolated but noting that the precise extent of the problem is unclear because no agency tracks these claims).

121. 2000 GAO REPORT, supra note 56, at 16 (describing this situation as one where the federal government is "paying twice").

122. Id. at 19.

123. The Judgment Fund is a "permanent, indefinite appropriation" that Congress created to pay judgments and settlements against the United States. Salazar v. Ramah Navajo Chapter, 132 S. Ct. 2181, 2193 n.8 (2012) (quoting 31 C.F.R. § 256.1 (2011)); see 31 U.S.C. § 1304 (2006 \& Supp. IV 2011) (specifying appropriate instances, including FTCA cases, where the Judgment Fund can be used). The Judgment Fund makes it easy for successful plaintiffs to collect. FIGLEY, supra note 20, at 144-45 (demonstrating the paltry amount of paperwork to be filed to receive automatic payment from the Judgment Fund). Before creation of the Judgment Fund, Congress had to appropriate individual sums to pay judgments to comply with the Constitution's Appropriations Clause. See U.S. ConsT. art. I, § 9, cl. 7 ("No Money shall be drawn from the Treasury, but in Consequence of Appropriations made by Law"); FigLEY, supra note 20, at 75-76 (discussing the reasons why Congress created the Judgment Fund).

124. See 2000 GAO REPORT, supra note 56, at 15 (noting that the tribes commonly carry private insurance covering activities also covered under the FTCA). 


\section{The discretionary function exception}

The convoluted theoretical problems behind extending the FTCA to tribal contractors make it difficult for courts to apply the FTCA's discretionary function exception in a consistent and meaningful way. Although the FTCA waives large portions of the United States' sovereign immunity, Congress was careful in reserving protection for discretionary functions carried out by employees of the United States acting within the scope of their employment. ${ }^{125}$ In passing the FTCA, Congress sought to waive the United States' immunity for ordinary common law torts committed by federal employees rather than to authorize new liability based on uniquely governmental functions. ${ }^{126}$ The Supreme Court has observed that protection for the government's discretionary activities has a long history in American jurisprudence. ${ }^{127}$ As such, Congress did not intend for the FTCA to allow suits to test the validity of the government's discretion. ${ }^{128}$ The Supreme Court characterized the discretionary function exception as “mark[ing] the boundary between Congress' willingness to impose tort liability upon the United States and its desire to protect certain governmental activities from exposure to suit by private individuals." ${ }^{129}$

In examining if the discretionary function shields the United States from liability for certain actions, courts consider whether (1) the challenged conduct involved an element of choice, and (2) the challenged conduct involved the kind of choice Congress meant to protect in enacting the discretionary function exception. ${ }^{130}$ The first prong of the test has a fairly straightforward application. ${ }^{131}$ In clarifying the second prong, the Supreme Court held that the challenged conduct must be undertaken in furtherance of public policy goals. ${ }^{132}$

125. 28 U.S.C. $\$ 2680(a)$; see United States v. S.A. Empresa de Viacao Aerea Rio Grandense (Varig Airlines), 467 U.S. 797, 808-09 (1984) (recounting the legislative history of the FTCA's discretionary function provision).

126. Dalehite v. United States, 346 U.S. 15, 28 n.19 (1953) (observing that "congressional thought was centered on granting relief for the run-of-the-mine accidents, as distinguished from injury from performing discretionary governmental functions").

127. See id. at 34 (describing the concept of discretionary function protection as "a concept of substantial historical ancestry in American law").

128. Id. at 30 (noting that discretionary function protection applies even when discretionary acts are negligently performed and involve an abuse of discretion).

129. Varig Airlines, 467 U.S. at 808.

130. Berkovitz v. United States, 486 U.S. 531, 536-37 (1988).

131. See id. (declaring that "conduct cannot be discretionary unless it involves an element of judgment or choice").

132. See United States v. Gaubert, 499 U.S. 315, 323 (1991) (reasoning that, in light of the discretionary function's purpose to "prevent judicial 'second-guessing' of 
The types of conduct protected by the discretionary function exception vary widely, from presidential decisions on issues of national security to a decision made by a park ranger in directing visitors around a moose. ${ }^{133}$ In United States v. Gaubert, ${ }^{134}$ the Court found the exception to protect the government from liability for decisions made by regulators of a savings and loan association. ${ }^{135}$ The exception applied even though the decisions themselves were at the day-to-day operational level rather than being large-scale policy decisions. ${ }^{136}$ Critics suggest that the exception is too broad and, in practice, has swallowed the rule by creating a broad category of cases where the government is immune from suit despite the FTCA's waiver of sovereign immunity. ${ }^{137}$

Because courts must consider tribal contractors to be federal employees under the Self-Determination Act, they too can invoke the

legislative and administrative decisions," the proper construction of the exception only protects government actions or "decisions based on considerations of public policy" (quoting Berkovitz et al. v. United States, 486 U.S. 531 (1988); Varig Airlines, 467 U.S. at 814)).

133. Compare Saltany v. Reagan, 702 F. Supp. 319, 321-22 (D.D.C. 1988) (declining to find the United States liable for damages related to President Reagan's decision ordering air strikes on Libya), with Tippett v. United States, 108 F.3d 1194, 1199 (10th Cir. 1997) (finding that a park ranger directing snowmobile riders around a moose was exercising a discretionary function and therefore was immune when a rider suffered an injury). See generally Paul F. Figley, Understanding the Federal Tort Claims Act: A Different Metaphor, 44 TORT TRIAL \& INS. PRAC. L.J. 1105, 1123-25 (2009) (characterizing the discretionary function as the most important one in the FTCA, and giving annotated examples of instances where courts have relied on the discretionary function exception to bar liability).

134. 499 U.S. 315 (1991).

135. Id. at $331,334$.

136. See id. at 325 ("Day-to-day management of banking affairs, like the management of other businesses, regularly requires judgment as to which of a range of permissible courses is the wisest.").

137. E.g., Allen v. United States, 816 F.2d 1417, 1424-25 (10th Cir. 1987) (McKay, J., concurring) (" $[\mathrm{T}]$ wo hundred years after we threw out King George III, the rule that 'the king can do no wrong' still prevails at the federal level in all but the most trivial of matters. ... . [T] he [FTCA ] . . is largely a false promise in all but 'fender benders' and perhaps some cases involving medical malpractice by government doctors."). Numerous commentators have called for changes to the FTCA's discretionary function exception. See, e.g., Marc C. Niles, "Nothing but Mischief": The Federal Tort Claims Act and the Scope of Discretionary Immunity, 54 ADMIN. L. REv. 1275, 1335 (2002) ("The discretionary function exception should apply to limit federal tort liability only in those rare circumstances when courts are called upon to adjudicate claims that require them to second guess discretionary policy decisions of the kind that should be left to political branches, or which call on courts to make the kinds of decisions that they are not equipped to make."); Jonathan R. Bruno, Note, Immunity for "Discretionary" Functions: A Proposal To Amend the Federal Tort Claims Act, 49 HaRv. J. ON LEgIS. 411, 444 (2012) (advocating for complete repeal of the discretionary function provision); James R. Levine, Note, The Federal Tort Claims Act: A Proposal for Institutional Reform, 100 Colum. L. REv. 1538, 1554 (2000) (proposing replacing the FTCA with an administrative agency tasked solely with resolving tort claims). 
broad protections of the discretionary function the same way an employee of a federal agency such as the BIA could. ${ }^{138}$ As a result, one sovereign gets to make policy decisions for another without risking liability. ${ }^{139}$ Other government contractors do not get this broad protection while carrying out government contracts. ${ }^{140}$ By deeming tribal contractors to be federal employees, Congress has added an extra layer to the FTCA's discretionary function exception.

The tribes can invoke the United States' protection under the discretionary function exception even for blatant negligence as long as there is an element of choice involved in their conduct because courts generally find contracts to be in furtherance of policy goals such as tribal self-determination. ${ }^{141}$ The discretionary function is a powerful shield that should not be applied haphazardly. ${ }^{142}$ Unlike federal employees, tribal contractors can invoke the discretionary function exception even where the federal government did not hire

138. See Hart v. United States, 630 F.3d 1085, 1090-91 (8th Cir. 2011) (applying the discretionary function to preclude liability where a BIA officer allowed a suspect to go back into his house before taking him to the police station and the suspect committed suicide while inside the house); Big Owl v. United States, 961 F. Supp. 1304, 1309 (D.S.D. 1997) (finding a tribal school board's decision not to renew a kindergarten teacher's contract to be based on considerations of public policy and protected by the discretionary function exception). The teacher in Big Owl was working pursuant to a contract under the Tribally Controlled Schools Act of 1988, Pub. L. No. 100-297, \$§ 5201-5212, 102 Stat. 130, 385-95 (codified as amended at 25 U.S.C. $\$ \S 2501-2511$ (2006)), which Congress passed to supplement the SelfDetermination Act. Big Owl, 961 F. Supp. at 1307. Employees working pursuant to that act are also deemed to be federal employees for FTCA purposes just like tribal employees working under Self-Determination Act contracts. Id.

139. See, e.g., Hinsley v. Standing Rock Child Protective Servs., 516 F.3d 668, 673 (8th Cir. 2008) (using the discretionary function exception to bar a claim against a tribal child protective services department employee who placed a child with a history of molesting other children in a foster home without warning the foster parents).

140. See infra Part II.C (discussing the FTCA's bar against federal government liability for contractor torts).

141. See, e.g., Hinsley, 516 F.3d at 673 (identifying the juvenile's interest in confidentiality as a public policy concern and barring a negligence claim when tribal child protective services placed a juvenile who was a known molester into a foster home without warning the family); Red Elk ex rel. Red Elk v. United States, 62 F.3d 1102, 1107 (8th Cir. 1995) (rejecting a negligent hiring claim when a tribe-employed police officer with a criminal record and history of alcohol abuse raped a minor while on duty); Locke v. United States, 215 F. Supp. 2d 1033, 1045 (D.S.D. 2002) (denying a negligent hiring claim based on the discretionary function when a tribal police officer assaulted a dispatcher), aff'd per curiam, 63 F. App'x 971 (8th Cir. 2003); Val-U Constr. Co. of S.D. v. United States, 905 F. Supp. 728, 737 (D.S.D. 1995) (finding hiring and firing of subcontractors under a Self-Determination Act contract to be protected by the discretionary function exception and noting that SelfDetermination Act contracts are firmly grounded in policy).

142. Vicki C. Jackson, Suing the Federal Government: Sovereignty, Immunity, and Judicial Independence, 35 GEO. WASH. INT'L L. REV. 521, 564 (2003) (describing the discretionary function exception as the most important FTCA exception and noting the expansive reading the Supreme Court has given it). 
them and has little-to-no involvement in their activities. ${ }^{143}$ The Department of Justice (DOJ) wields the power of the discretionary function exception carefully to protect the kinds of policy choices Congress had in mind when passing the FTCA. ${ }^{144}$ Courts have little guidance in applying the discretionary function exception to tribal contracting because Congress's extension of the FTCA to the tribes is fundamentally incompatible with the discretionary function exception. ${ }^{145}$ Congress left little legislative history with the extension of the FTCA and courts essentially must make an unguided choice. ${ }^{146}$ This result leads to uncertainty for the tribes as to what will be covered, which defeats the primary purpose of extending the FTCA to tribal contractors. ${ }^{147}$

Replacing FTCA coverage with subsidized private insurance would prevent courts from having to determine whether certain functions were the kind that Congress meant to protect, ${ }^{148}$ a determination that courts currently struggle with due to the different policy considerations behind the FTCA and the Self-Determination Act. ${ }^{149}$

143. See, e.g., Garcia v. United States, No. 3:09-CV-08033-JWS, 2011 WL 285860, at *9 (D. Ariz. Jan. 27, 2011) (suggesting that the discretionary function exception would have barred the claim of negligent hiring of a tribal police officer who drank on the job before causing a major car accident); see also Cabazon Band of Mission Indians v. Smith, 388 F.3d 691, 696 n.6 (9th Cir. 2004) (observing that although tribal police officers working under Self-Determination Act contracts are considered federal employees, the BIA has no authority to supervise day-to-day activities).

144. See H.R. REP. No. 77-2245, at 10 (1942) ("Nor is it desirable or intended that the constitutionality of legislation, or the legality of a rule or regulation should be tested through the medium of a damage suit for tort.").

145. Congress expressly excluded contractors from the FTCA. 28 U.S.C. $\$ 2671$ (2006); see Statement on Signing Department of the Interior and Related Agencies Appropriations Act, 1991, 2 PUB. PAPERS 1558, 1559 (Nov. 5, 1990) (noting the contradiction between the purpose of tribal self-determination and the FTCA practice of granting immunity to contractors only when under strict government supervision).

146. See supra Part I.C (discussing the legislative history of the extension of the FTCA to tribal contractors and suggesting that practical considerations regarding costs to the tribes drove the decision, which seemed to gloss over any possible legal issues that could come with this kind of extension of the FTCA).

147. See Marlys Bear Med. v. United States ex rel. Sec'y of the Interior, 241 F.3d 1208, 1217 (9th Cir. 2001) (analyzing individual actions performed under a SelfDetermination Act contract and finding some to be covered by the discretionary function and others not); see also infra note 203 and accompanying text (contending that uncertainty in coverage often leads the tribes to purchase private liability insurance in case the FTCA does not cover them, even though Congress sought to save the tribes from incurring this cost).

148. See United States v. Gaubert, 499 U.S. 315, 322-23 (1991) (suggesting that to be eligible for protection under the FTCA, conduct must be the kind Congress sought to protect).

149. Congress passed the Self-Determination Act to give the tribes the tools needed to achieve increased independence in governance. S. REP. No. 93-682, at 13 (1974). When Congress extended the FTCA to tribal contractors, it gave no guidance on how to reconcile the objectives of tribal self-governance with the FTCA's 
The tribes would still have authority over their own members and would be free to pass their own laws protecting discretionary functions for torts committed against tribal members. ${ }^{150}$

\section{B. Scope of Employment: Applying the FTCA to Tribal Contractors Makes It Difficult To Determine if Tribal Employees Are Acting Within the Scope of Employment}

The FTCA only waives the government's sovereign immunity when a tort is committed by a federal employee acting within the scope of his or her employment. ${ }^{151}$ Pursuant to the Westfall Act ${ }^{152}$ if the DOJ investigates and, if satisfied, certifies that an alleged employee tortfeasor acted within the scope of his or her employment, the United States substitutes itself as the defendant. ${ }^{153}$ If the DOJ declines to certify that the tortfeasor acted within the scope of his or her employment, the tortfeasor can challenge this determination in federal court. ${ }^{154}$

Because the FTCA incorporates state law as the law of the place in tort suits, ${ }^{155}$ some variation is to be expected among the jurisdictions as courts use state law to determine scope of employment. ${ }^{156}$ Still, deeming Indian contractors to be federal employees is problematic. This section will explore the difficulties of making the scope-ofemployment determination for tribal contractors by first exploring

limited waiver of federal sovereign immunity. Statement on Signing Department of the Interior and Related Agencies Appropriations Act, 1991, 2 PUB. PAPERS 1558, 1559 (Nov. 5, 1990) (noting the fundamental inconsistencies between the FTCA and its application to tribal contractors).

150. See Nevada v. Hicks, 533 U.S. 353, 359 (2001) (finding the sovereign powers of an Indian tribe not to extend to nonmembers except in protecting tribal government or controlling tribal relations).

151. 28 U.S.C. \$ 1346(b) (1) (2006).

152. Federal Employees Liability Reform and Tort Compensation Act of 1988, Pub. L. No. 100-694, 102 Stat. 4563 (codified at 16 U.S.C. § 831c-2, 28 U.S.C. $§ \S ~ 2671$, 2674, 2679 (2006)).

153. 28 U.S.C. \& $2679(\mathrm{~d})(1)$

154. Id. $\$ 2679$ (d) (3); see Gutierrez de Martinez v. Lamagno, 515 U.S. 417, 424-25 (1995) (resolving a circuit split to hold that Congress intended these certifications to be reviewable in federal court regardless of whether the DOJ certifies that the employee is within the scope of employment).

155. See 28 U.S.C. $\$ 1346$ (b) (1) (stating that the correct law to be applied in the FTCA is the "law of the place" of the wrong); FDIC v. Meyer, 510 U.S. 471, 478 (1994) (observing that courts have consistently found state law to be the applicable law in FTCA cases).

156. See, e.g., Primeaux v. United States, 181 F.3d 876, 879 (8th Cir. 1999) (en banc) (interpreting a vicarious provision of the Restatement of Agency under South Dakota law to determine whether a tribal police officer was acting within the scope of his employment when he raped a young woman he picked up); Mentz v. United States, 359 F. Supp. 2d 856, 861 (D.N.D. 2005) (looking to the Second Restatement of Agency under North Dakota law to determine whether a tribal school employee was acting in the scope of his employment under North Dakota law). 
the difficulties in applying these concepts to the tribes, which often are structured in ways unlike the federal government. Next this section will examine the role of Indian country and the potential problems it could create.

\section{Non-traditional tribal employees}

Non-traditional tribal employment situations make it difficult to consistently determine whether tribal contractors are acting within the scope of employment. Frequently, the tribes have different organizational structures than government agencies, ${ }^{157}$ and federal courts lack analogous FTCA cases. ${ }^{158}$ Sometimes, for example, members of the tribal council seek to be covered as employees of the government. ${ }^{159}$ The DOJ addresses these situations on a case-by-case basis, but some tribes have accused it of having a blanket policy of denying certification that tribal council members are acting within the scope of their employment. ${ }^{160}$

In some situations, tribal leaders serve in multiple capacities, making it difficult for courts to determine if the alleged tortfeasors are acting within the scope of employment. In Big Crow v. Rattling Leaf ${ }^{161}$ for example, Robert Rattling Leaf served as the Rosebud Sioux's Director of Natural Resources, but he was also commissioned as a law enforcement officer. ${ }^{162}$ Rattling Leaf responded to a law enforcement call on his radio, and, in the process, caused a fatal car accident. ${ }^{163}$ The district court overturned the DOJ's refusal to certify him as a federal employee. ${ }^{164}$ The court found him to be acting as a federal employee within the scope of his employment even though

157. See Katherine J. Florey, Choosing Tribal Law: Why State Choice-of-Law Principles Should Apply To Disputes with Tribal Contacts, 55 AM. U. L. REv. 1627, 1689 (2006) (suggesting that tribal courts get a cultural benefit from having their own practices and procedures that may be different from those in state or federal courts).

158. See, e.g., Big Crow v. Rattling Leaf, 296 F. Supp. 2d 1067, 1069 (D.S.D. 2004) (observing that a precise issue of tribal employment involving a tribal leader was one of first impression).

159. See 2000 Senate Tribal Tort Liability Hearing, supra note 101, at 8-9 (statement of Ethan M. Posner, Deputy Assoc. Att'y Gen.) (suggesting that this determination is very fact-specific).

160. See id. at 20-21 (defending the DOJ against charges that it had a blanket policy of refusing to certify members of the tribal council when they are involved in an FTCA claim). Deputy Associate Attorney General Posner's statement alludes to a case in Nebraska in which the DOJ refused to certify some tribal council members as within the scope of employment. Id. The statement does not address the case by name and it did not yield a reported decision, perhaps because the plaintiff found little utility in pursuing an individual capacity suit.

161. 296 F. Supp. $2 d 1067$ (D.S.D. 2004).

162. Id. at 1069 .

163. $I d$.

164. Id. at $1070-71$. 
the tribe had several different Self-Determination Act contracts and Rattling Leaf was not technically hired by or paid under the contract to provide law enforcement services. ${ }^{165}$ Cases like Big Crow show the operational difficulties that courts encounter when determining tribal contractor scope of employment; and policy considerations, rather than a strict reading of the relevant laws, may weigh heavily on courts faced with these situations. ${ }^{166}$

In other cases where courts struggle in applying the FTCA to tribal contractors, tribal employees have non-traditional roles. In Adams $v$. Tunmore, ${ }^{167}$ a federal district court found a Jesuit volunteer given a small monthly stipend through the tribe's general fund to be a federal employee because the court determined she was carrying out part of a tribal school's grant when she caused a car accident. ${ }^{168}$ The tribe furnished her with a vehicle and she assisted with educational programs at the tribal school. ${ }^{169}$ The court overturned the government's denial to certify her as an employee and found her to be within the scope of her employment when she crashed the car near the school while "finish[ing] up preparations" to leave the reservation. ${ }^{170}$ This decision is dubious because it considers the source of the volunteer's payment to be irrelevant. ${ }^{171}$ The Adams decision illustrates the difficulties of determining the scope of employment in the tribal context because state tort law lacked analogues to this kind of employment arrangement.

165. Id. at 1070 ("It was obviously, if nothing else, the 'custom' and a 'procedure' of the Tribe to have [Rattling Leaf] assist other law enforcement officers operating under the 638 contract. . . . No requirement can be found in statute, regulation, or contract to the effect that a tribal employee paid under one self-determination contract cannot be performing functions under another self-determination contract.").

166. See $i d$. (taking judicial notice that Indian reservations often lack properly trained law enforcement officers).

167. No. CV-05-270-FVS, 2006 WL 2591272 (E.D. Wash. Sept. 8, 2006).

168. See $i d$. at $* 3$ (noting that tribal school employees get the same FTCA protections as tribal contractors working pursuant to Self-Determination Act contracts).

169. See id. at *1 (noting that the volunteer assisted with reading, art, and soccer).

170. See id. at $* 4$ (finding this situation to fall under an exception to the general "coming and going" rule because she was driving a company car).

171. Id. at *3 (citing Big Crow v. Rattling Leaf, 296 F. Supp. 2d 1067, 1070 (D.S.D. 2004)). In Big Crow, however, there were two separate Self-Determination Act contracts and it was customary for the officer to be paid under one and assist in performance of the other. 296 F. Supp. 2d at 1069-70. In Adams, the volunteer was paid a stipend out of the tribe's general fund, which does not come from the federal government. 2006 WL 2591272, at*3. Had the court ruled the other way in Adams, a volunteer could have been liable for a large damages award. 
A few tribes are structured like the federal government, ${ }^{172}$ but the Self-Determination Act does not require them to be, ${ }^{173}$ and as a result, courts and the DOJ struggle to determine when the FTCA covers tribal contractors. ${ }^{174}$ In some cases, courts seem willing to override the DOJ's certification and let policy considerations create a very broad scope of employment for indirect tribal employees. ${ }^{175}$ Adding an extra layer to the scope of employment issue by including the tribes makes applying any state's test difficult, however, because the employees are only employees of the federal government as a result of a statutorily codified legal fiction. ${ }^{176}$ Extending the FTCA to tribal contractors makes it difficult for courts to apply state scope-ofemployment law with any regularity, thereby creating more uncertainty in whether tribal employees involved in specific actions will be covered, which undermines the purpose of extending the FTCA to the tribes. ${ }^{177}$ If the tribes cannot be confident that their employees carrying out Self-Determination Act contracts will be covered under the FTCA, savvy tribes will purchase liability insurance to protect themselves from the risk of tort liability. ${ }^{178}$ In extending the FTCA, however, Congress sought to eliminate the burden of the tribes buying private insurance. ${ }^{179}$ Due to this confusion, sophisticated tribes wanting to protect themselves from liability are no better off than they were before Congress started this experiment with the FTCA. ${ }^{180}$

172. See, e.g., Navajo Nation Code AnN. tit. 2, § 1 (2009) (creating three branches of government-executive, judicial, and legislative).

173. See Florey, supra note 157, at 1689 (suggesting that the tribes get a cultural benefit by not completely conforming their legal systems to western practice).

174. Adams, 2006 WL 2591272, at *4 (relying on an exception to the general "coming and going" rule instead of delving into the complexities of tribal contracting law).

175. See, e.g., Big Crow, 296 F. Supp. 2d at 1070-71 (citing the Attorney General's refusal to certify the tribal Natural Resources Director as within the scope of his employment while responding to law enforcement call as an example of the maxim "[n] good deed goes unpunished"); see also Garcia v. United States, No. Civ. 08$0295 \mathrm{JB} / \mathrm{WDS}, 2010 \mathrm{WL} 2977611$, at *17-19 (D.N.M. June 15, 2010) (finding an offduty tribal police officer to be within the scope of employment when he intervened in a physical altercation at a family wedding because the wedding guests knew he was a police officer and expected him to intervene and he was to report to work only two hours later).

176. See Big Crow, 296 F. Supp. 2d at 1068-69 (discussing the statutory scheme governing tribal contracting).

177. See 2000 GAO REPORT, supra note 56, at 34 (identifying the lack of clear guidance in the Self-Determination Act as to which tribal employees are covered as a problem in the statutory scheme).

178. See id. at 18 (noting that many tribes still carry private liability insurance).

179. See supra Part I.C (discussing the history of the Self-Determination Act).

180. See 2000 Senate Tribal Tort Liability Hearing, supra note 101, at 10 (statement of Michael Willis, Hobbs, Straus, Dean and Walker Law Offices) (suggesting that 


\section{Indian country}

The FTCA only applies to federal employees acting within the scope of employment. ${ }^{181}$ Self-Determination Act contracts are generally carried out in Indian country. ${ }^{12}$ Defining the scope of Indian country is a complex and thorny issue that has not been entirely resolved. ${ }^{183}$ Questions about the boundaries of Indian country could add a great deal of uncertainty to a court's determination of whether a tribal contractor is acting within the scope of employment. Although the government has not yet litigated this strategy, this section serves as a warning of a future problem looming on the horizon.

The relevant statutes governing tribal contracting generally apply to services provided in "Indian country," which is a term of art in Indian law. ${ }^{184}$ Federal law generally defines Indian country as "land within the limits of any Indian reservation," "dependent Indian communities" whether within a tribe's original or subsequently acquired territory, and "Indian allotments." 185 Even though Indian country has a standardized statutory definition, the boundaries of

insurance companies do not lower their rates to account for areas already covered by the FTCA).

181. See Gutierrez de Martinez v. Lamagno, 515 U.S. 417, 423 (1995) (describing scope of employment as the dividing line between suits against the federal government under the FTCA and individual capacity suits against government employees).

182. The Self-Determination Act sought to turn over to the tribes programs previously being run by the BIA. S. REP. No. 93-682, at 13 (1974). Initially the BIA claimed that it provided services only on Indian reservations based on provisions in its manual, but in practice provided them to Indian communities near reservations, too. Morton v. Ruiz, 415 U.S. 199, 210-11 (1974). These "dependent Indian communities" living near reservations have now been codified as part of "Indian country" and are served by the BIA. 18 U.S.C. $\S 1151$ (2006). The boundaries of Indian country are especially important in contracts for law enforcement. See 25 U.S.C. § 2802(a) (noting that ILERA applies to law enforcement in Indian country). Whether an officer is within Indian country could affect the determination of whether he is within the scope of employment. See, e.g., Garcia v. United States, No. 3:09-CV-08033 JWS, 2011 WL 285860, at *3 (D. Ariz. Jan. 27, 2011) (noting that a provision in the Self-Determination Act contract under which the officer was hired specified that officers were always considered to be on duty while they were in Indian country).

183. See Matthew L.M. Fletcher, The Supreme Court's Indian Problem, 59 Hastings L.J. 579, 599-602 (2008) (decrying the current state of the Supreme Court's Indian law decisions and suggesting that the Court drastically redefine Indian country); Gloria Valencia-Weber, Shrinking Indian Country: A State Offensive To Divest Tribal Sovereignty, 27 ConN. L. REv. 1281, 1282 (1995) (claiming that the amount of Indian country is shrinking); Gloria Valencia-Weber, The Supreme Court's Indian Law Decisions: Deviations from Constitutional Principles and the Crafting of Judicial Smallpox Blankets, 5 U. PA. J. CONST. L. 405, 473 (2003) (suggesting that the statute defining Indian country is merely an attempt to describe Indian lands as an incoherent "checkerboard" pattern of Indian lands).

184. 18 U.S.C. $\$ 1151$.

185. Id. 
Indian country are not always clear in practice, as is particularly true in Alaska, Oklahoma, and areas in the country where Indian and nonIndian lands form a "checkerboard" pattern. ${ }^{186}$ For example, unlike all other states, tribal land in Alaska is divided between native corporations. ${ }^{187}$ The unique situation in Alaska means there is little or no Indian country left in that state, ${ }^{188}$ even though there is a significant native population. ${ }^{189}$ As a result, the BIA enters into SelfDetermination Act contracts with Alaska native tribes. ${ }^{190}$ The status of Indian country in Alaska remains unsettled. ${ }^{191}$ In Oklahoma there is also a debate over the scope of Indian country. ${ }^{192}$

186. See Alaska v. Native Vill. of Venetie Tribal Gov't, 522 U.S. 520, 532 (1998) (suggesting that the Alaska Native Claims Settlement Act (ANCSA), Pub. L. No. 92203, 85 Stat. 688 (1971) (codified as amended at 43 U.S.C. $\$ \$ 1601-1629 \mathrm{~h}$ (2006)), which converted reservations to native corporations, showed Congress's intent to set aside tribal lands which diminishes Indian country); Okla. Tax Comm'n v. Sac \& Fox Nation, 508 U.S. 114, 124 (1993) (acknowledging the argument that there may be no more reservations in Oklahoma based on an 1891 treaty, but still finding there to be Indian country); Sarah Krakoff, A Narrative of Sovereignty: Illuminating the Paradox of the Domestic Dependent Nation, 83 OR. L. REV. 1109, 1185 (2004) (describing the pattern of Indian and non-Indian lands in New Mexico as a "checkerboard" and noting that the result has been longstanding disputes over jurisdiction between the state and the tribes). See generally COHEN's HandBoOK OF FEDERAL Indian LAW, supra note $46, \S 4.07$ (discussing the historical status of Indian country in Oklahoma and Alaska).

187. See Venetie, 522 U.S. at 523 (concluding that 1.8 million acres of land in northern Alaska is not Indian country); see also Geoffrey D. Strommer \& Stephen D. Osborne, "Indian Country" and the Nature and Scope of Tribal Self-Government in Alaska, 22 Alaska L. REV. 1, 5-6 (2005) (providing background on the ANCSA and the current status of Indian country in Alaska).

188. See Venetie, 522 U.S. at $527 \&$ n.2 (commenting that with the exception of the Annette Island Reserve, there are no Indian reservations in Alaska); Strommer \& Osborne, supra note 187, at 5 (stating that the ANCSA "extinguished" most Indian country in Alaska); cf. John v. Baker, 982 P.2d 738, 752 (Alaska 1999) (suggesting that although Congress may have extinguished most of Indian country in Alaska, it did not extinguish all powers the tribes possess as sovereigns).

189. See Research \& ANAlysis Section, Alaska DeP'T OF Labor \& Workforce Dev., Alaska Population Overview: 2010 Census AND 2011 Estimates 12 \& tbl.1.4 (2012), available at http://almis.labor.state.ak.us/pop/estimates/pub/popover.pdf (reporting that American Indian and Alaska natives constituted 17\% of the Alaskan population in 2010).

190. See 2008 Senate Self-Determination Act Hearing, supra note 68, at 2 (statement of Sen. Lisa Murkowski, Vice Chairman, S. Comm. on Indian Affairs) (noting the prevalence of self-governance programs among Alaskan tribes).

191. See, e.g., Tribal Law and Order Act of 2010, Pub. L. No. 111-211, § 205, 124 Stat 2258, 2264 (including an explicit provision that nothing in the bill alters the jurisdiction of the state of Alaska, rather than clearly defining what constitutes Indian country there).

192. See Kirke Kickingbird, "Way Down Yonder in the Indian Nations, Rode My Pony Cross the Reservation!" from "Oklahoma Hills" by Woody Guthrie, 29 TuLSA L.J. 303, 328-30 (1993) (addressing the survey that reported that the state had no reservations and Congress's subsequent decision to follow the survey's recommendation of jurisdiction over Indian reservations); Angela M. Risenhoover, Note, Reservation Disestablishment: The Undecided Issue in Oklahoma Tax Commission v. Sac and Fox 
Further complicating the matter, the Supreme Court has recognized Indian country as extending to dependent Indian communities living off of established reservations. ${ }^{193}$ Dependent Indian communities are now included in the statutory definition of Indian country. ${ }^{194}$ The Supreme Court has established a two-part test for determining whether tribal areas are dependent Indian communities: The tribe must show the land is a federal set-aside and that it is under federal superintendence. ${ }^{195}$

Self-Determination Act contracts let the tribes take over services formerly provided by the BIA in Indian country. If an employee was outside Indian country, he or she could be outside the scope of the contract and therefore outside the scope of his or her employment. The DOJ could then refuse to certify the person as within the scope of his or her employment and the United States would not be substituted as the defendant. ${ }^{196}$ If the DOJ does not certify the employee in question as being within the scope of employment, the plaintiff can either proceed with an individual capacity suit or challenge the determination in federal court. ${ }^{197}$ Furthermore, taken to its logical end, a court could find certain Self-Determination Act contracts to be void if they are performed outside of Indian country when doing so is unauthorized by statute. ${ }^{198}$

Critics might argue that taking such a position would violate the canon of statutory construction that courts should interpret laws in favor of Indians when the law is not clear. ${ }^{199}$ Courts reading laws in a light favorable to the tribes, however, need not ignore clear manifestations of intent. ${ }^{200}$ Congress has consistently specified that all

Nation, 29 Tulsa L.J. 781, 783-85 (1994) (discussing Oklahoma's history as Indian territory and rebutting the argument that there is no Indian country there).

193. See Morton v. Ruiz, 415 U.S. 199, 215-16 (1974) (detailing the prevalence of Indian communities near but not on the reservation); $i d$. at 229 (refusing to allow the BIA to unilaterally amend its policy manual to provide assistance only to reservation Indians).

194. 18 U.S.C. $\$ 1151$ (2006).

195. Alaska v. Native Vill. of Venetie Tribal Gov't, 522 U.S. 520, 527 (1998).

196. Osborn v. Haley, 549 U.S. 225, 241 (2007) (noting that when the government refuses to certify that an employee was within the scope of employment, the Westfall Act's protections do not apply).

197. Gutierrez de Martinez v. Lamagno, 515 U.S. 417, 419-20 (1995).

198. See Tex. \& P. Ry. Co. v. Pottorff, 291 U.S. 245, 260 (1934) (stating that no contractual rights arise from an ultra vires contract, even though the contract has been performed).

199. See Bryan v. Itasca County, 426 U.S. 373, 392 (1976) (describing the Indian canon of statutory construction as an "eminently sound and vital canon" (quoting $\mathrm{N}$. Cheyenne Tribe v. Hollowbreast, 425 U.S. 649, 655 n.7 (1976))).

200. See South Dakota v. Yankton Sioux Tribe, 522 U.S. 329, 349 (1998) (clarifying that the Indian canon of construction is not "a license to disregard clear expressions 
statutes governing Indian contracting apply in Indian country. ${ }^{201}$ The government, however, does not always speak with one clear voice and the DOJ may determine that clarifying the boundaries of Indian country serves the greater goal of self-determination, even if it may put the department at odds with another department, or tribes, in a particular case.

Uncertainty about the boundaries of Indian country could call into question when tribal contractors are covered under the FTCA. ${ }^{202}$ This uncertainty about Indian country could lead to potential gaps in coverage, making it less clear if and when the tribes need to purchase private insurance, thus undermining Congress's purpose in applying the FTCA to the tribal contractors. ${ }^{203}$ The DOJ has not yet refused to certify a Self-Determination Act contractor as outside the scope of employment based on the boundaries of Indian country, but the lack of clarity regarding the boundaries of Indian country could foreshadow future problems. ${ }^{204}$ As the tribes contract for more functions under the Self-Determination Act, it seems likely that they will push the boundaries of Indian country. ${ }^{205}$ Therefore these issues may arise, making it difficult, if not impossible, for courts to determine whether the employee in question was acting within the scope of employment. Congress extended the FTCA to make it easier for the tribes to enter into Self-Determination Act contracts, and yet Congress may have unwittingly opened the door for complex legal battles over coverage.

of tribal and congressional intent" (quoting DeCoteau v. Dist. Cnty. Court for the Tenth Judicial Dist., 420 U.S. 425, 447 (1975)) ).

201. See supra Part I.B-D (discussing the statutes governing tribal contracting and tracing their legislative history).

202. The tribes already find FTCA coverage to be limited and overly complex. See 2000 Senate Tribal Tort Liability Hearing, supra note 101, at 95 (suggesting that the relatively low number of FTCA claims stems from the tribes' lack of familiarity with the existence of both insurance and FTCA claims).

203. Cf. 2000 GAO RePORT, supra note 56, at 15 (noting that the tribes often purchase private liability insurance). It would be hard to know when the tribes needed to purchase insurance if it is unclear whether tribal contracts outside of Indian country are covered by the FTCA.

204. Contesting a contractor as being outside the scope of Indian country and therefore the scope of employment could be desirable in a particularly blatant case of abuse.

205. See 2008 Senate Self-Determination Act Hearing, supra note 68, at 2 (statement of Sen. Lisa Murkowski, Vice Chairman, S. Comm. on Indian Affairs) (describing the Indian Self-Determination Act contracting as a "success story" and noting that the program now includes "over 230 tribes compacting an estimated $\$ 350$ million for the BIA and over 380 tribes and tribal organizations compacting over $\$ 1.2$ billion within the [Indian Health Service]"). 


\section{Contractors: Covering Tribal Contractors Contravenes the FTCA's Clear and Longstanding Exclusion of Government Contractors}

Applying the FTCA to torts committed by tribal contractors directly contravenes the FTCA's policy barring government liability for torts committed by government contractors. ${ }^{206}$ In passing the FTCA, Congress expressly declined to waive the United States' sovereign immunity for claims against government contractors. ${ }^{207}$ Congress has amended the Self-Determination Act to cover torts committed by tribal contractors with the FTCA even though the claims would be clearly barred otherwise. ${ }^{208}$ This position is also inconsistent with Congress's treatment of other Indian programs-Congress waived the United States' sovereign immunity for torts arising from SelfDetermination Act contracts, but not for some other programs such as those that the Department of Housing and Urban Development (HUD) provides to aid the tribes. ${ }^{209}$

Courts can deem a non-Indian contractor to be an employee of the United States for FTCA purposes, but only if the government controls the detailed physical aspects of the contractor's operations. In adopting this standard, the Supreme Court set a high bar. ${ }^{210}$ In United States v. Logue, ${ }^{211}$ for example, private prison guards were found to be contractors rather than federal employees even though the prison was run according to stringent regulations from the Bureau of Prisons. ${ }^{212}$ The Court found that the FTCA did not cover the prison guards because the government did not physically supervise their conduct. ${ }^{213}$ Therefore, on remand, the plaintiffs could only proceed against the government under the FTCA for the actions of specific

206. See 28 U.S.C. $\$ 2671$ (2006) (excluding contractors from the definition of federal agency, thereby placing them outside the reach of the FTCA).

207. Id.

208. See Letter from John R. Bolton, Assistant Att'y Gen., to Sen. Daniel K. Inouye, supra note 57, at 60 (describing the DOJ's continual resistance to applying the FTCA to tribal contractors).

209. See Comes Flying v. United States, 830 F. Supp. 529, 530 (D.S.D. 1993) (denying an FTCA claim where the tribe's contract with the government is through HUD and is not a Self-Determination Act contract).

210. See, e.g., Bravo v. United States, 532 F.3d 1154, 1160 (11th Cir. 2008) (finding a civilian doctor working at a Navy hospital to be deemed a government employee for FTCA purposes where his contract stated that his "activities shall be subject to day-to-day direction by Navy personnel in a manner comparable to the direction over

Navy uniformed and civil service personnel engaged in comparable work").

211. 412 U.S. 521 (1973).

212. Id. at 529-30.

213. Id. at 530 . 
agents at the prison who were actual federal employees. ${ }^{214}$ The purpose of tribal contracting, however, is that the federal government does not exercise such a high level of control over the tribes. ${ }^{215}$ As such, the United States expressly does not control the day-to-day operations of these tribal contractors because doing so would be inappropriate and against the policy of Indian self-determination. ${ }^{216}$

The question, then, becomes only whether the tribe exercised the necessary amount of control to make the contractor an employee of the tribe. ${ }^{217}$ For example, in Necklace v. United States, ${ }^{218}$ a tribe in South Dakota hired Isaac Primeaux to clear ice from a pedestrian walkway. ${ }^{219}$ The same day Primeaux was hired, the tribe immediately sent him out in a truck towing a flatbed trailer with a skid loader on it. ${ }^{220}$ That day, he was involved in an accident that killed two other motorists. ${ }^{221}$ The accident occurred when the trailer disengaged from the pickup truck he was driving. ${ }^{222}$ A court found the worker to be a federal

214. See Logue v. United States, 488 F.2d 1090, 1091-92 (5th Cir. 1974) (per curiam) (discussing the Supreme Court's findings and remanding the case to the district court for findings of fact on the negligence of a U.S. deputy marshall).

215. See S. REP. No. 93-682, at 12-13 (1974) (emphasizing the recognition of tribal sovereignty and the shift towards self-governance); Statement on Signing Department of the Interior and Related Agencies Appropriations Act, 1991, 2 PuB. PAPERS 1558, 1559 (Nov. 5, 1990) (describing the extension of the FTCA to tribal contractors as undermining efforts to foster tribal autonomy); see also Letter from John R. Bolton, Assistant Att'y Gen., to Sen. Daniel K. Inouye, supra note 57, at 59-60 (suggesting that Congress justifies applying the FTCA to tribal contractors based on their importance but observing that the same argument could be made about any number of other government contractors such as personnel at Veterans Administration hospitals).

216. See Statement on Signing Department of the Interior and Related Agencies Appropriations Act, 1991, 2 PUB. PAPERS 1558, 1559 (identifying the tension between supervision and control, on the one hand, and tribal autonomy, on the other); see, e.g., Cabazon Band of Mission Indians v. Smith, 388 F.3d 691, 696 n.6 (9th Cir. 2004) (observing that although the tribal police officers working pursuant to SelfDetermination Act contracts are considered federal employees for FTCA purposes, the BIA has no authority to oversee the day-to-day operations of the officers).

217. See Andrade ex rel. Goodman v. United States, No. 05-3240-PHX-MHM, 2008 WL 4183011, at*8 n.1 (D. Ariz. Sept. 8, 2008) ("Because the [Self-Determination Act contracts] contemplate that the Colorado River Indian Tribe would administer a social services program on behalf of the Federal Government, the issue is not whether the Bureau of Indian Affairs exercised sufficient control over [the tribe's Child Protective Services], but whether [the tribe or its social services office] exercised control over [the tribe's Child Protective Services] in a manner consistent with that of a principal-agent relationship."). In Andrade, the plaintiff alleged that the tribe's social services knew or should have known that two children it placed in foster care were dangerous before the abusive children sexually abused another child in the foster home. Id. at $* 1$.

218. No. Civ. 06-4274, 2007 WL 3389926 (D.S.D. Nov. 14, 2007).

219. Id. at *1.

220. Id. at *3 (noting that all of the equipment used was not owned by the tribal entity which had entered into the Self-Determination Act contract).

221. Id. at $* 1$.

222. Id. 
employee for FTCA purposes even though he was on his way to clear snow from a sidewalk when the Self-Determination Act contract provided for road maintenance and the equipment he was using did not belong to the tribal road maintenance program. ${ }^{223}$ The court noted that policy considerations favoring tribal contracting played a role in its decision. ${ }^{24}$ The level of control necessary to make a worker an employee of a tribal contractor depends on state agency law, but is generally much lower than the amount of control the federal government must exercise to deem employees of contractors federal employees for FTCA purposes. ${ }^{225}$ In a typical FTCA contractor case there would be little question if the person in question was an employee of the contractor and the primary issue would be whether the government exercised enough control over their performance to make them a federal employee. ${ }^{226}$ Under the current system for tribal contractors, the only necessary inquiry is whether the worker is an employee of the tribal contractor. ${ }^{227}$ As a result, within hours of the tribe hiring an unskilled laborer in Necklace, the federal government was potentially liable for a large judgment.

Extending FTCA coverage to government contractors even if they do not meet the traditional requirements is not entirely unprecedented, although it is exceedingly rare. Congress has also extended the FTCA to cover nuclear weapons testing. ${ }^{228}$ That issue, however, involves national security concerns not present with the Indian tribes. ${ }^{229}$ Furthermore, Congress had already agreed to pay

223. Id. at $* 5-7$.

224. See id. at *5-6 (suggesting that the government should give the tribes maximum flexibility and remove obstacles to entering into Self-Determination Act contracts with the tribes).

225. Compare Logue v. United States, 412 U.S. 521, 530 (1973) (finding a prison guard in a federal prison not to be a federal employee for FTCA purposes because even though the prison was run according to detailed federal specifications, the government did not physically supervise the guards in question), with Necklace, 2007 WL 3389926, at *1, *7 (holding a tribe member involved in a deadly crash to be an employee of the tribe, and thus covered under the FTCA, even though he had been hired the morning of the accident and given no training). After the district court ruled that the employee was covered by the FTCA, the United States conceded liability for the deadly crash. Necklace v. United States, No. CIV. 06-4274, 2009 WL 2191881, at *1 (D.S.D. July 20, 2009).

226. Logue, 412 U.S. at 526.

227. Necklace, 2007 WL 3389926, at *6-7.

228. See 50 U.S.C. $\$ 2783$ (c) (2006) (providing FTCA coverage to certain nuclear weapons testing contractors); see also In re Consol. U.S. Atmospheric Testing Litig., 820 F.2d 982, 990-91 (9th Cir. 1987) (discussing the legislative history of the bill which extended FTCA protection to nuclear weapons contractors).

229. See Atmospheric Testing, 820 F.2d at 987 (suggesting that nuclear weapons contractors are "instruments of national policy to assist in an entirely governmental task-nuclear weapons research"). Some events, such as nuclear attack, are thought to be uninsurable. See Michelle E. Boardman, Known Unknowns: The Illusion of 
judgments against nuclear weapons contractors before extending the FTCA to cover them. ${ }^{230}$ In other limited instances involving national security considerations, the Supreme Court has recognized a government contractor defense, which is a federal common law defense with roots in sovereign immunity. ${ }^{231}$ The Court, however, relied on other doctrines that would not be relevant in the tribal context. $^{232}$

Courts do apply the FTCA's contractor exclusion to subcontractors working on Self-Determination Act contracts. $^{233}$ Excluding

Terrorism Insurance, 93 GEO. L.J. 783, 784 (2005) (arguing that insurers do not find it profitable to insure "a catastrophic event that causes significant losses across multiple 'lines' of insurance"). Even though the government did not control the detailed physical aspects of the work, Congress justified the extension of the FTCA to the nuclear contractors because "[o]nly the government sets policy, makes decisions, and controls activities and circumstances regarding atomic weapons testing." Atmospheric Testing, 820 F.2d at 987 (citing the legislative history of the extension of the FTCA to cover nuclear weapons testing).

230. See Atmospheric Testing, 820 F.2d at 990-91 (tracing the legislative history of the extension of the FTCA to nuclear weapons contractors). The government would have had to pay potential judgments without the ability to assert the FTCA's defenses. See id. at 991 (noting that in the context of nuclear weapons testing, the Feres doctrine and the discretionary function exception would be powerful defenses). 231. See Boyle v. United Techs. Corp., 487 U.S. 500, 511 (1988) (holding one element of the government contractor defense to be that specifications for military equipment were grounded in policy considerations like those protected by the discretionary function exception). But see Sean Watts, Note, Boyle v. United Technologies Corp. and the Government Contractor Defense: An Analysis Based on the Current Circuit Split Regarding the Scope of the Defense, 40 WM. \& MARY L. REv. 687 (1999) (suggesting that there is an unresolved circuit split over the extent to which government contractors can invoke Boyle to protect themselves from lawsuits).

232. See Boyle, 487 U.S. at 512-13 (displacing state law for claims against manufacturers of military equipment when the government approved the design with reasonably precise specifications, the equipment met those specifications, and the supplier notified the government of all dangers). This area of the law is not well established and has been called into question by subsequent decisions. See Hercules, Inc. v. United States, 516 U.S. 417, 435 (1996) (Breyer, J., dissenting) (describing the "contemporaneous legal uncertainty" surrounding Boyle). For example, the evolution of the Boyle doctrine has lead to a conflation of sovereign immunity and preemption in the context of military contractors serving overseas, creating confusion regarding the appropriate defense and the extent of the government's liability. See Kathryn R. Johnson, Note, Shields of War: Defining Military Contractors' Liability for Torture, 61 AM. U. L. REv. 1417, 1429-31 (2012) (arguing that preemption is the appropriate defense because it insulates the government's legitimate interests in military operations from state tort law claims while also preserving a forum for contractor actions that exceed legitimate governmental functions covered by the FTCA). The Supreme Court has not addressed the issue since the Boyle decision. See Stephen I. Vladeck, The New National Security Canon, 61 AM. U. L. Rev. 1295, 1306-07 (2012) (discussing cases in other circuits that have addressed the issue after Boyle).

233. See Demontiney v. U.S. ex rel. Dep't of Interior, 255 F.3d 801, 808 (9th Cir. 2001 ) (finding that a subcontractor cannot take advantage of the Self-Determination Act because he was not working pursuant to a Self-Determination Act contract); FGS Constructors, Inc. v. Carlow, 64 F.3d 1230, 1234-35 (8th Cir. 1995) (limiting the definition of a contractor for Self-Determination Act purposes to the tribes and "tribe-related" organizations). 
subcontractors presents a significant barrier to recovery for plaintiffs, particularly in regards to Indian health centers. ${ }^{234}$ Indian health centers, run pursuant to Self-Determination Act contracts, provide important medical care to tribal populations. ${ }^{235}$ The tribes enter into Self-Determination Act contracts to run the health centers, but often subcontract out many of the centers' key functions. ${ }^{236}$ When these subcontractors commit torts, they are generally not covered by the FTCA, and therefore claims against the United States are barred because the United States has not waived its sovereign immunity for these claims. ${ }^{237}$ Congress extended the FTCA to cover most tribal contractors, ${ }^{238}$ yet some of the people who could commit the most serious torts against tribal members receiving services are not covered. ${ }^{239}$ This situation is not unique to tribal contractors, as the complex problem of determining whether certain personnel are federal employees or contractors often arises at federal healthcare facilities. ${ }^{240}$ In this instance, applying the FTCA to tribal contractors subjects the tribes to the same complexities the federal government

234. See, e.g., Tsosie v. United States, 452 F.3d 1161, 1167 (10th Cir. 2006) (finding that a physician at an IHS facility was an independent contractor and therefore that the claim was barred by the FTCA even though the health center itself was run pursuant to a Self-Determination Act contract); Bernie v. United States, 712 F.2d 1271, 1273-74 (8th Cir. 1983) (same); see also Wooten v. Hudson, 71 F. Supp. 2d 1149, 1154 (E.D. Okla. 1999) (finding a doctor to be an employee of the United States for FTCA purposes at certain times and an employee of a contractor at other times). But see Bird v. United States, 949 F.2d 1079, 1088 (10th Cir. 1991) (finding a nurse to be an employee of the government rather than of a contractor because he was acting as an integral part of the operating team when the incident occurred).

235. See 2008 Senate Self-Determination Act Hearing, supra note 68, at 2 (statement of Sen. Lisa Murkowski, Vice Chairman, S. Comm. on Indian Affairs) (discussing the prevalence of Indian health facilities in Alaska and their importance in providing care to hard-to-reach tribal populations).

236. See, e.g., Wooten, 71 F. Supp. 2d at 1151-52 (noting that the hospital contracted out emergency room services, although the subcontractors were required to carry malpractice insurance).

237. See, e.g., Bernie, 712 F.2d at 1273 (applying the day-to-day control and supervision standard from Logue and Orleans to find that doctors were not acting as federal employees).

238. See supra Part I.C (discussing Congress's decision to extend the FTCA to tribal contractors to avoid having the tribes purchase private liability insurance for each Self-Determination Act contract they enter).

239. See supra note 234 (exposing the complexities of coverage for subcontractors under the FTCA, and providing instances where front-line medical personnel may not be covered).

240. Compare Creel v. United States, 598 F.3d 210, 214-15 (5th Cir. 2010) (finding an orthopedic surgeon at a Veterans Affairs (VA) hospital to be an independent contractor and therefore dismissing the suit against the United States under the FTCA), with Ezekiel v. Michel, 66 F.3d 894, 900 (7th Cir. 1995) (concluding that a medical resident in a VA training program was a government employee for FTCA purposes rather than an independent contractor even though the hospital did not directly employ him). 
deals with in operating medical facilities, undermining the goal of simplifying tort coverage for the tribes.

By directly contravening the FTCA's clear statutory bar against waiving the United States' sovereign immunity for torts committed by contractors, Congress has created a situation where courts are in the untenable position of having to choose between attempting a mechanical application of a law that does not really fit the tribal contractor context and trying to reconcile the purpose behind it. Furthermore, tribal contractors are covered but subcontractors are not. ${ }^{241}$ The result is unsatisfactory because some of the front line medical personnel for whom purchasing private insurance would be the most expensive are not covered. ${ }^{242}$ Subcontractors, therefore, must purchase liability insurance and presumably pass the costs on to the tribes, defeating Congress's purpose of reducing costs for the tribe to enter into Self-Determination contracts. ${ }^{243}$ Congress should end the experiment with the FTCA and instead help the tribes buy comprehensive private insurance to prevent courts from having to apply a law that does not fit the tribal contractors and would make tort litigation simpler for both the tribes and tort victims.

D. Law Enforcement: FTCA Coverage of Tribal Contractors Makes the United States Liable for Some Serious Abuses While Barring Other Actions that Would Proceed if a Traditional Federal Employee Injured the Victim

Applying the FTCA to tribal contractors contravenes the FTCA's treatment of law enforcement officers and intentional torts by barring torts that might otherwise be actionable against government employees. Initially, the United States maintained its sovereign immunity for all claims for specified intentional torts, but, in 1974, Congress amended the FTCA to cover certain intentional torts committed by law enforcement officers. ${ }^{244}$ Congress added this provision, referred to as the "law enforcement proviso," because of

241. See supra notes 233-237 and accompanying text (addressing the FTCA's applicability to tribal subcontractors).

242. See supra note 234 (giving examples of situations where courts use the FTCA to bar claims against subcontractors).

243. See 2000 Senate Tribal Tort Liability Hearing, supra note 101, at 10 (statement of Michael Willis, Hobbs, Straus, Dean and Walker Law Offices) (lamenting the current situation where the tribes still have to buy private liability insurance to insure activities not covered by the FTCA but insurers cannot actually reduce costs because neither the tribes nor the insurance companies know precisely what is covered under the FTCA).

244. Act of Mar. 16, 1974, Pub. L. No. 93-253, § 2, 88 Stat. 50 (codified at 28 U.S.C. $\$ 2680(\mathrm{~h})(2006))$. 
concerns over aggressive law enforcement raids. ${ }^{245}$ The law enforcement proviso is an exception to the intentional tort exception. ${ }^{246}$ Generally, the FTCA does not waive sovereign immunity for intentional torts, but the law enforcement proviso waives the United States' sovereign immunity for "[a]ny claim arising out of assault, battery, false imprisonment, false arrest, malicious prosecution, abuse of process, libel, slander, misrepresentation, deceit, or interference with contract rights," provided they are committed by federal law enforcement officers. ${ }^{247}$ The statute defines a law enforcement officer as "any officer of the United States who is empowered by law to execute searches, to seize evidence, or to make arrests for violations of Federal law." ${ }^{248}$ Furthermore, in claims not covered by the law enforcement proviso, courts have read the FTCA's intentional tort bar to cover claims ultimately sounding in negligence but stemming from a battery committed by a government employee. ${ }^{249}$ The general intentional tort exception "does not merely bar claims for assault or battery; in sweeping language it excludes any claim arising out of assault or battery." 250 Unless the law enforcement proviso applies, a plaintiff cannot succeed in an FTCA case for an intentional tort, even if the plaintiff tries to recharacterize the incident as a negligent tort.

Tribal law enforcement is an important function for which the tribes enter into Self-Determination Act contracts and it generates

245. See, e.g., Bivens v. Six Unknown Named Agents of Fed. Bureau of Narcotics, 403 U.S. 388, 389 (1971) (describing how agents handcuffed the plaintiff in front of his family, threatened to arrest his wife and children, searched his apartment thoroughly, and eventually interrogated him and conducted a visible strip search). A Bivens suit allows an injured party to bring a lawsuit against a federal officer in his or her individual capacity without specific statutory authorization. 6 FEDERAI Procedure, LAWYERS' EdITION $\$ 11: 244$, at 303-04 (West 2004). Congress created the FTCA's law enforcement proviso as a counterpart to Bivens suits. S. REP. No. 93588, at 3 (1973).

246. FigLEY, supra note 20, at 34 .

247. 28 U.S.C. $\$ 2680(\mathrm{~h})(2006)$.

248. Id.

249. E.g., Lambertson v. United States, 528 F.2d 441, 444-45 (2d Cir. 1976) (affirming the trial court's dismissal of an FTCA negligence suit under the intentional tort exception where a meat inspector, in a prank gone awry, jumped on a colleague's back and caused him to run into meat hooks, finding the incident arose out of a battery, despite plaintiff pleading negligence).

250. United States v. Shearer, 473 U.S. 52, 55 (1985) (plurality opinion); cf. Sheridan v. United States, 487 U.S. 392, 395, 403 (1988) (allowing an FTCA negligence claim to proceed where government employees at Bethesda Naval Medical Center allowed a patient to leave with a loaded rifle which the patient later used to fire at passing motorists because the "[g] overnment has a duty to prevent a foreseeably dangerous individual from wandering about unattended"). 
more FTCA claims than any other function. ${ }^{251}$ Because Congress extended FTCA protection to tribal contractors, they are deemed to be employees of the federal government for FTCA purposes, but often these cases turn on whether the alleged tortfeasor was acting as a federal law enforcement officer, which is a separate designation. ${ }^{252}$ Under a BIA contract, tribal law enforcement officers are not automatically considered federal law enforcement officers, but they may be commissioned as such on a case-by-case basis. ${ }^{253}$ The regulations clearly contemplate that the tribes could contract for law enforcement but have officers who fall short of technically being federal law enforcement officers. ${ }^{254}$

Often tribal police departments work in conjunction with BIA officers who are federal law enforcement officers, but this cooperation alone is not enough to make the tribal law enforcement officers federal law enforcement officers for FTCA purposes. ${ }^{255}$ For tribal officers to execute federal law, the tribe must first execute cross deputation agreements and issue Special Law Enforcement Commissions (SLECs). ${ }^{256}$ SLECs are agreements that allow tribal officers to enforce federal law. ${ }^{257}$ Tribal officers can be eligible for an SLEC once they have met certain requirements, such as receiving a firearms certification and maintaining a felony-free criminal record. ${ }^{258}$

251. 2000 GAO REPORT, supra note 56, at 9 (noting that certain tribes' law enforcement contracts account for a high number of FTCA claims).

252. See, e.g., Henin v. Cancel, 708 F. Supp. 2d 1315, 1319 (S.D. Fla. 2010) (finding that a Miccosukee police officer was a federal employee for FTCA purposes but not a federal law enforcement officer, so the law enforcement proviso was not triggered and the FTCA's intentional tort exception applied to block the claim).

253. 25 C.F.R. $\$ 12.21$ (b) (2012).

254. Id.; see Bertagna, supra note 11, at 605 ("The Secretary of the Interior's regulations and related memoranda illustrate how Indian tribes must take affirmative steps to have tribal officers authorized to enforce federal law, but no regulations or memoranda mention any need of power or approval from the BIA for tribes to enforce their own tribal laws.").

255. See, e.g., Trujillo v. United States, 313 F. Supp. 2d 1146, 1150 (D.N.M. 2003) (explaining that the mere existence of the contract is not enough to make the officers federal law enforcement for the FTCA); Locke v. United States, 215 F. Supp. 2d 1033, 1038 (D.S.D. 2002) (characterizing cooperation between tribal officers and federal law enforcement officers as "common knowledge" but declining to find the tribal officer in question to be a federal law enforcement officer for FTCA purposes), aff'd per curiam, 63 F. App'x 971 (8th Cir. 2003).

256. See Bertagna, supra note 11, at 605 (describing the process for allowing tribal police officers to enforce federal law).

257. 25 U.S.C. $\$ 2803$ (2006); e.g., Hebert v. United States, 438 F.3d 483, 484 (5th Cir. 2006) (pointing out the overlap in tribal, federal, and local jurisdictions and observing that the officer in question had a SLEC to enforce the law of all three jurisdictions in certain circumstances).

258. Internal Law Enforcement Services Policies, 69 Fed. Reg. 6321, 6322 (Feb. 10, 2004). 
In situations where tribal law enforcement officers are not crossdeputized and not authorized to carry out federal law, these more stringent requirements do not apply, and the tribes are free to hire and train officers who do not comply with federal regulations. ${ }^{259}$ In some cases, like Red Elk ex rel. Red Elk v. United States, ${ }^{260}$ the United States is held liable for the extreme actions of tribal police officers that it did not hire, train, or supervise, but who are found to be acting within the scope of employment. ${ }^{261}$ In Red Elk, a South Dakota tribe hired a police officer despite the fact that he had no experience, a criminal record, and a history of alcohol abuse. ${ }^{26}$ Despite the officer's repeated poor performance reports and inappropriate behavior at work, the tribe continued to employ him. ${ }^{263}$ He was ultimately convicted of criminal charges for raping a minor he picked up on a curfew violation. ${ }^{264}$ The U.S. Court of Appeals for the Eighth Circuit, in the civil suit, found it to be foreseeable that a male officer might do this to a female arrestee, and therefore found him to be acting within the scope of his employment under state law. ${ }^{265}$ The court affirmed the district court's ruling against the United States, holding the federal government liable for the tribal officer's blatant and outrageous misconduct, even though the United States did not hire or supervise the officer and the officer may not have met government hiring standards. ${ }^{266}$ The court in Red Elk incorrectly reasoned that imposing liability would make the tribe more accountable, ${ }^{267}$ even though the United States rather than the tribe would pay the claim.

259. See, e.g., Red Elk ex rel. Red Elk v. United States, 62 F.3d 1102, 1104 (8th Cir. 1995) (noting that the tribal officer in question was hired despite a history of alcohol abuse and a number of misdemeanor convictions).

260. 62 F.3d 1102 (8th Cir. 1995).

261. Id. at 1108 .

262. Id. at 1104

263. Id.

264. See United States v. Claymore, 978 F.2d 241, 425 (8th Cir. 1992) (sentencing the officer to sixty months in prison).

265. Red Elk, 62 F.3d at 1107; $c f$. Primeaux v. United States, 181 F.3d 876, 882 (8th Cir. 1999) (en banc) (finding an off-duty BIA officer to be outside the scope of his employment where he gave a girl a ride in his car and then raped her, and distinguishing the case from Red Elk because the officer was providing the kind of assistance a civilian would provide).

266. See Red Elk, 62 F.3d at 1104 \& n.3 (noting the officer's ten prior misdemeanor convictions); see also id. at 1108 (suggesting that imposing liability would improve hiring and supervision).

267. See id. at 1108 ("This type of justified liability, hopefully, may help improve hiring and supervision, and produce a police force fully worthy of the public trust."); see also St. John v. United States, 240 F.3d 671, 677 (8th Cir. 2001) (reaffirming the Eighth Circuit's Red Elk decision and its statement on "justified liability"). 
Other courts have drawn fine lines to protect the United States from liability for torts committed by tribal law enforcement by finding that tribal officers are federal employees for FTCA purposes but are not federal law enforcement officers. ${ }^{268}$ In these instances, the law enforcement proviso is not triggered and the intentional tort exception bars the claim. ${ }^{269}$ This is the result even though the claim could proceed if the officer was working directly for the BIA. ${ }^{270}$ Locke v. United States ${ }^{271}$ illustrates how tribal law enforcement officers are sometimes considered to be federal employees but not federal law enforcement officers. In Locke, a tribal police officer assaulted a tribal police dispatcher by putting an air gun to the back of her head and pulling the trigger several times. ${ }^{272}$ The court found the officer to be a federal employee, but because he had not received a commission to enforce federal law, he was not a law enforcement officer within the meaning of the FTCA. ${ }^{273}$ Therefore the claim against the United States was barred under the intentional tort exception. ${ }^{274}$

268. See, e.g., Dry v. United States, 235 F.3d 1249, 1257-58 (10th Cir. 2000) (finding a tribal police officer to be a federal employee for FTCA purpose but not a federal law enforcement officer and therefore the law enforcement proviso was not triggered and the FTCA's intentional tort exception barred the claim); Buxton v. United States, No. CIV. 09-5057, 2011 WL 4528337, at *8 (D.S.D. Apr. 1, 2011) (same), adopted by No. Civ. 09-5057-JLV, 2011 WL 4528329 (D.S.D. Sept. 28, 2011); United States v. Medearis, 775 F. Supp. 2d 1110, 1119 (D.S.D. 2011) (same); Henin v. Cancel, 708 F. Supp. 2d 1315, 1319 (S.D. Fla. 2010) (same); Bob v. United States, No. CIV. 07-5068RHB, 2008 WL 818499, at *3 (D.S.D. Mar. 26, 2008) (same); Johnson v. United States, No. CIV. 06-1023, 2007 WL 2688556, at *3 (D.S.D. Sept. 11, 2007) (same), aff'd, 534 F.3d 958 (8th Cir. 2008); Washakie v. United States, No. CV-05-462E-BLW, 2006 WL 2938854, at *4 (D. Idaho Oct. 13, 2006) (same); Trujillo v. United States, 313 F. Supp. 2d 1146, 1150 (D.N.M. 2003) (same); Vallo v. United States, 298 F. Supp. 2d 1231, 1237 (D.N.M. 2003) (same); Locke v. United States, 215 F. Supp. 2d 1033, 1038-39 (D.S.D. 2002) (same), aff'd per curiam, 63 F. App'x 971 (8th Cir. 2003).

269. See, e.g., Trujillo, 313 F. Supp. 2d at 1149 ("Nothing in the [SelfDetermination Act], or in relevant case law, suggests that the mere existence of a Public Law 93-638 contract between BIA and a tribe for the provision of law enforcement services automatically confers federal law enforcement authority upon the officers in tribal police departments.").

270. See, e.g., Jackson v. United States, 33 F. App’x 293, 294-96 (9th Cir. 2002) (not barring intentional tort claims in an FTCA case against a BIA officer, but finding that the plaintiff failed to sufficiently prove the elements of the tort); St. John, 240 F.3d at 678 (not applying the intentional tort exception to claims against a BIA officer, but remanding the case for further finding of fact); Waybenais v. United States, 769 F. Supp. 306, 309 (D. Minn. 1991) (identifying BIA officers as federal law enforcement officers, therefore triggering the law enforcement proviso and allowing the suit to proceed).

271. 215 F. Supp. 2d 1033 (D.S.D. 2002), aff'd per curiam, 63 F. App’x 971 (8th Cir. 2003).

272. Id. at 1035 .

273. Id. at $1038-39$.

274. Id. at 1039 . 
Other courts find that regardless of an officer's ability to enforce federal law, an officer who is enforcing tribal law, and not federal law, at the time of the incident is not a law enforcement officer within the meaning of the FTCA and therefore the intentional tort exception bars claims for negligent torts. ${ }^{275}$ For example, in Hebert $v$. United States, ${ }^{276}$ the officer in question had a SLEC, but the U.S. Court of Appeals for the Fifth Circuit found him not to be enforcing federal law. ${ }^{277}$ Although the reasoning is different from the cases that focus on whether officers have federal law enforcement commissions, the result is the same and the plaintiff's claim is barred. ${ }^{278}$

The 2000 GAO Report identified the inconsistent results of these cases as particularly troubling. ${ }^{279}$ By barring these claims under the intentional tort exception to the FTCA, courts recognize that Indian law enforcement officers should not be treated as federal law enforcement officers unless they have the requisite training. At the same time, however, victims of intentional torts by Indian law enforcement officers are left without effective recourse. ${ }^{280}$ The

275. See Hebert v. United States, 438 F.3d 483, 487 (5th Cir. 2006) (finding a tribal police officer with a SLEC not to be enforcing federal law, and thus not a law enforcement officer under the FTCA, when he responded to a domestic dispute at a casino); Shirk v. United States. ex rel. Dep't of Interior, No. CV-09-01786-PHX-NVW, 2010 WL 3419757, at *5 (D. Ariz. Aug. 27, 2010) (finding tribal police officers not to be enforcing federal or tribal law, and thus not law enforcement officers under the FTCA, when they were accused of negligently allowing a drunk driver to leave a traffic stop before he ultimately collided with a motorcycle); Boney v. Valline, $597 \mathrm{~F}$. Supp. 2d 1167, 1174-75 (D. Nev. 2009) (barring an FTCA claim because a tribal police officer was found not to be enforcing federal law when he used lethal force against the decedent in an incident related to a traffic stop for drunk driving).

276. 438 F.3d 483 (5th Cir. 2006).

277. See id. at 487 (reasoning that the court did not need to determine exactly what law the officer was enforcing at the time of the incident because the officer was not acting within the scope of his federal employment).

278. See id. (finding the officer was not a federal law enforcement officer to trigger the law enforcement proviso and therefore the FTCA's intentional tort exception barred the plaintiff's claim).

279. See 2000 GAO REPORT, supra note 56, at 33-34 (observing that a large amount of these kinds of claims are for intentional torts committed by tribal law enforcement officers, which are increasingly being barred because courts find the officers in question not to be federal law enforcement officers for purposes of the FTCA); see also 2000 Senate Tribal Tort Liability Hearing, supra note 101, at 53 (statement of Barry T. Hill, Director, Energy, Resources, and Science Issues, Resources, Community, and Economic Development Division, General Accounting Office) (suggesting this line of cases illustrates that the FTCA may be a poor fit for tribal contractors).

280. See, e.g., Trujillo v. United States, 313 F. Supp. 2d 1146, 1152 (D.N.M. 2003) (dismissing all of the plaintiff's claims). Indians could potentially pursue a suit in tribal court, but nonmembers may not be able to do so. See Strate v. A-1 Contractors, 520 U.S. 438, 445 (1997) (stating that "absent express authorization by federal statute or treaty, tribal jurisdiction over the conduct of nonmembers exists only in limited circumstances"). If the tribes in the cases in question had not entered into Self-Determination Act contracts for law enforcement services, the BIA would have continued to provide the services and the victims could have brought a claim under 
current situation gives courts a Hobson's choice by requiring them to choose between applying the letter of the law-which would protect the United States from liability for intentional torts committed by tribal law enforcement officers - and the purpose behind Congress's extension of the FTCA to tribal contractors - which is to provide the same coverage the government would have had if it did not contract out these activities to the tribes.

Law enforcement provides yet another example of the conflict between established FTCA principles and Congress's extension of the FTCA to tribal contractors. By squeezing a square peg into a round hole, Congress forces courts to mechanically apply the FTCA in ways that go against the principles and jurisprudence underpinning it. ${ }^{281}$ The resulting case law is inconsistent, providing the tribes that contract for critical law enforcement functions with little guidance as to which of their actions may be covered under the FTCA. ${ }^{282}$

\section{E. Law of the Place: Covering Tribal Contracts with the FTCA Raises Problematic Choice-of-Law Issues}

In FTCA cases, federal courts apply the law of the place where the incident occurred. ${ }^{283}$ Virtually without exception, that has meant state law. After a federal court in New Mexico suggested that tribal law should govern, Indian law commentators began advocating for applying tribal law in FTCA cases. This section first examines the FTCA's choice-of-law jurisprudence and then argues against using tribal law in FTCA cases. Regardless of whether courts address the issue directly or through state choice-of-law provisions, federal courts should not use tribal law as the law of the place in FTCA suits.

\section{FTCA choice-of-law jurisprudence}

An overarching concern in all of the issues discussed in this Comment is choosing which law to apply in FTCA suits involving tribal contractors. Applying the FTCA to tribal contractors raises the possibility that courts could use tribal law in FTCA suits, resulting in courts applying the law of another sovereign, whose law it cannot

the FTCA. See, e.g., St. John v. United States, 240 F.3d 671, 679 (8th Cir. 2001) (upholding a judgment for false arrest and false imprisonment against a BIA police officer).

281. See supra Part II.A (discussing the theoretical inconsistencies that come from applying the FTCA to tribal contractors).

282. See 2000 GAO REPORT, supra note 56, at 35 (noting the uncertainty among the tribes as to precisely what the FTCA covers, in part due to the DOJ's unpredictable decisions regarding which cases get representation).

283. 28 U.S.C. \$1346(b) (1) (2006). 
effectively discern, to determine the United States' liability in tort. ${ }^{284}$ The Supreme Court and virtually all other courts considering which law to apply in FTCA cases have interpreted the FTCA's "law of the place" to mean state law. ${ }^{285}$ State law means the whole state law, which includes state choice-of-law provisions to determine which state's law to apply. ${ }^{286}$ By using the whole law, the Supreme Court created the possibility of courts using the law of the place's choice-oflaw rules to choose the law of another state to govern liability. ${ }^{287}$ Federal courts should not use tribal law as the law of the place in FTCA suits because it directly contradicts a whole body of FTCA jurisprudence that applies state law.

Furthermore, Congress, in crafting the FTCA, was explicitly unwilling to subject the United States to tort liability based on other nations' laws. ${ }^{288}$ Courts deciding whether to apply tribal law can look

284. See Cheromiah v. United States, 55 F. Supp. 2d 1295, 1305 (D.N.M. 1999) (ruling that Acoma Pueblo law would govern a medical malpractice case brought under the FTCA); infra notes 328-333 and accompanying text (discussing the difficulties inherent in accurately determining tribal law).

285. See FDIC v. Meyer, 510 U.S. 471, 478 (1994) (suggesting the Supreme Court had "consistently held" the law of the place to mean state law); Miree v. DeKalb County, 433 U.S. 25, 29 n.4 (1977) (asserting that "the Federal Tort Claims Act itself looks to state law in determining liability"); Richards v. United States, 369 U.S. 1, 14 n.29 (1962) (admitting that there is some ambiguity with regard to choice-of-law issues under the FTCA but concluding from the legislative materials that Congress intended state law as the law of the place); CNA v. United States, 535 F.3d 132, 138 (3d Cir. 2008) (noting that a claim would not be cognizable under the FTCA if it were not cognizable under state law); LaFromboise v. Leavitt, 439 F.3d 792, 794 (8th Cir. 2006) (declining to apply tribal law in an FTCA case and giving examples of other courts reaching the same conclusion); Ochran v. United States, 273 F.3d 1315, 1317 (11th Cir. 2001) (suggesting that the FTCA was passed to provide liability for ordinary torts as defined by state law and the court does not have jurisdiction unless such a claim is made); Schwarder v. United States, 974 F.2d 1118, 1124 (9th Cir. 1992) ("Congress plainly intended to define the contours of a 'tort claim' by reference to state law.").

286. See Richards, 369 U.S. at 14 (providing that Congress intended state law to apply in FTCA cases and finding no reason for that to exclude state choice-of-law provisions); see also Florey, supra note 157, at 1668 (arguing that state conflict-of-laws analysis could result in the application of tribal law); Katherine C. Pearson, Departing from the Routine: Application of Indian Tribal Law Under the Federal Tort Claims Act, 32 ARIZ. ST. L.J. 695, 724 (2000) (making a similar argument but concluding that such analysis might be unnecessary because of the "black letter rule approach of the FTCA").

287. See James A. Shapiro, Choice of Law Under the Federal Tort Claims Act: Richards and Renvoi Revisited, 70 N.C. L. REv. 641, 643-45 (1992) (professing that the effect has been courts choosing the state's law where the plaintiff will have the largest recovery).

288. See United States v. Spelar, 338 U.S. 217, 221 (1949) ("Congress was ready to lay aside a great portion of the sovereign's ancient and unquestioned immunity from suit, [but] it was unwilling to subject the United States to liabilities depending upon the laws of a foreign power."). But cf. Cherokee Nation v. Georgia, 30 U.S. (5 Pet.) 1, 17 (1831) (categorizing the tribes as "domestic dependent nations"); Cheromiah v. United States, 55 F. Supp. 2d 1295, 1308 (D.N.M. 1999) (finding the tribes not to be foreign nations because they cannot enter treaties). 
to the FTCA's statutory bar on liability for torts arising in foreign nations. ${ }^{289}$ The Supreme Court has examined the legislative history of the FTCA's foreign tort exception and found that Congress declined to waive sovereign immunity for torts arising in foreign countries because it was unwilling to subject the United States to liability based on the law of a foreign entity. ${ }^{290}$ Though the Indian tribes are not a foreign nation, ${ }^{291}$ the foreign tort exception also applies to areas where there is no clear sovereign. ${ }^{292}$ Some of the same considerations apply when deciding if a domestic dependent nation's laws will govern the United States' liability in tort. ${ }^{293}$ Applying tribal law to FTCA cases raises the same concerns about predictability and variation that has given courts pause about applying foreign law. ${ }^{294}$

Despite the inconsistency with well-established FTCA jurisprudence, commentators have addressed the issue and argued in favor of using tribal law in FTCA cases. One commentator has argued that courts considering which law to apply in FTCA claims against tribal contractors should reverse the trend and apply tribal law as a way of showing respect for tribal sovereignty. ${ }^{295}$ Another commentator looks to additional provisions in the Self-Determination Act as suggesting that tribal employment and contract preference laws will govern with respect to the administration of these contracts. $^{296}$ The section cited by this commentator, however, comes

289. See 28 U.S.C. $\$ 2680(\mathrm{k})(2006)$.

290. See Spelar, 338 U.S. at 221-22 (dismissing a suit for a tort claim on a U.S. military base in Newfoundland, Canada because adjudicating the claim would require applying Canadian law as the law of the place).

291. See Cherokee Nation, 30 U.S. at 17 (categorizing the tribes as "domestic dependent nations" protected by the United States).

292. See Smith v. United States, 507 U.S. 197, 201 (1993) (applying the FTCA's foreign tort exception to bar a claim for negligence arising at a research facility in Antarctica).

293. See Sosa v. Alvarez-Machain, 542 U.S. 692, 707 (2004) (suggesting the purpose of the foreign tort exception is to avoid the application of substantive foreign law because Congress was unwilling to subject the United States to another country's law). But cf. Cheromiah, 55 F. Supp. 2d at 1308 (rejecting outright arguments based on the FTCA's foreign tort exception).

294. See infra notes 354-356 (discussing the difficulties in applying tribal law to FTCA cases).

295. See Reed C. Easterwood, Comment, Indian Self-Determination: The Federal Government, New Mexico, and Tribes in the Wake of Cheromiah, 38 N.M. L. Rev. 453, 456 (2008) (advancing application of tribal law as a way to foster cooperation between the federal government and the tribes). But see Florey, supra note 157, at 1689 (observing that in order to apply tribal law in state or federal courts, the tribes would have to develop their law in a way that is more similar to the law in those courts, which may detract from the cultural benefits of the tribes having their own methods of decision-making).

296. See Christie, supra note 10, at 128 (arguing that because Congress allowed for limited application of tribal law during tribal contract disputes, it 
from a separate section of the Self-Determination Act than the provisions governing tort liability and FTCA coverage, and the author provides no evidence as to why the two sections should be read together. ${ }^{297}$ Another commentator contends that the federal courts choosing to apply state law rather than tribal law reflects animus towards the tribes. $^{298}$ This line of argument suggests that applying federal law would be unfairly using the law of the conqueror. ${ }^{299}$ Another author uses a choice-of-law analysis under state law to ultimately apply tribal law. ${ }^{300}$ Using state choice-of-law provisions to choose tribal law, however, is still inconsistent with established FTCA jurisprudence regarding the law of the place and could subject the United States to liability under a myriad of laws, which may be difficult, if not impossible to accurately discern and interpret in federal court. ${ }^{301}$

\section{Practical concerns with applying tribal law in FTCA suits}

The possibility of applying tribal law in an FTCA suit assumes federal courts are able to accurately discern and apply tribal law. Concerns over federal courts applying tribal law are not merely theoretical; two federal courts have actually found tribal law to be the governing law in FTCA cases. $^{302}$ In the most prominent case,

must have also intended for tribal law to govern choice of law in FTCA suits (citing 25 U.S.C. $\$ 450 \mathrm{e}$ (c) (2006))).

297. See id. (offering no further evidence of congressional intent to apply tribal law in FTCA cases, or explanation as to why that particular and separate section of the Self-Determination Act should apply). Compare 25 U.S.C. $\$ 450 \mathrm{e}(\mathrm{c})$ (governing wage and labor standards), with id. $\$ 450 \mathrm{f}$ (c) (governing liability insurance).

298. See Easterwood, supra note 295 , at 474 (contending that the rare application of tribal law "exposes" the alleged antipathy directed to tribal governments and laws).

299. Id. at 453-54. Easterwood does not, however, object to using the FTCA as the exclusive remedy for these claims, but rather wants the deep-pocketed federal government to defend tribal contractors as governed by tribal law. $C$ f. id. (declining to address the regulations making the FTCA the exclusive remedy for tribal contractor torts).

300. See Florey, supra note 157, at 1654 (suggesting that modern conflict of laws analysis involves examining an array of factors to determine which law of the state has the "most significant relationship" to the incident); Pearson, supra note 286, at 724 (noting the Second Restatement's flexible standard for determining which state has the most significant relationship to the case). But see cases cited infra note 338 (providing examples of where courts did not apply tribal law).

301. See Florey, supra note 157, at 1630 (discussing difficulties inherent in applying tribal law in federal courts, including language barriers and procedural issues).

302. Harvey v. United States (Harvey II), No. 08CV107 MCA/CG, 2011 BL 177075, at * 4-7 (D.N.M. June 30, 2011), aff'd on other grounds, 685 F.3d 939 (10th Cir. 2012); Cheromiah v. United States, 55 F. Supp. 2d 1295, 1305 (D.N.M. 1999). But see LaFromboise v. Leavitt, 439 F.3d 792, 794 (8th Cir. 2006) (collecting cases considering the issue and reaching the opposite conclusion). 
Cheromiah v. United States, ${ }^{303}$ a federal district court in New Mexico issued a ruling that the law of the Acoma Pueblo would govern a suit alleging medical malpractice at an IHS facility. ${ }^{304}$ In Cheromiah, a young man died after doctors at an IHS hospital on the Acoma Pueblo reservation failed to diagnose a deadly bacterial infection despite four trips to the emergency room. ${ }^{305}$ The key reason for applying tribal law, however, had nothing to do with respecting tribal sovereignty, but rather that New Mexico law included a cap on medical malpractice damages while tribal law did not. ${ }^{306}$ The court dismissed other cases reaching the opposite conclusion, suggesting that in those cases these arguments were not adequately raised and "the fact that it has never been done, standing alone, does not mean that it is not what the law requires." 307 This argument simply dismisses all of the instances where courts applied state law as situations where neither the litigants nor the court thought of applying tribal law. ${ }^{308}$

Furthermore, at least one of the cases that the Cheromiah court cited discussed the issue in some depth and decided not to apply tribal law. ${ }^{309}$ The Cheromiah court also reasoned that applying tribal

303. 55 F. Supp. 2d 1295 (D.N.M. 1999).

304. Id. at 1305 .

305. Id. at 1297 .

306. See id. at 1309 (quoting a 1995 decision from the Acoma Pueblo which found the New Mexico cap of $\$ 600,000$ "repugnant" to the traditions of the tribe). But see Defendant's Response to Plaintiff's Motion for Partial Summary Judgment at 6, Harvey v. United States, No. 08CV107 MCA/RLP (D.N.M. Sept. 29, 2009), 2008 WL 7195310 (noting that the Acoma Pueblo adopted the New Mexico medical malpractice cap shortly after Cheromiah). See generally John Bernard Corr, Modern Choice of Law and Public Policy: The Emperor Has the Same Old Clothes, 39 U. Miami L. REV. 647, 694 (1985) (commenting that there "will be an irreducible number of cases in which courts will be inclined to employ public policy doctrine" in deciding choice-of-law questions, which may not be "doctrinally consistent").

307. Cheromiah, 55 F. Supp. $2 \mathrm{~d}$ at 1306.

308. Id. The court dismissed a large and diverse body of case law. See, e.g., LaFromboise v. Leavitt, 439 F.3d 792, 793 (8th Cir. 2006) (applying North Dakota law where alleged malpractice occurred at a government-operated medical facility on an Indian reservation); Red Elk ex rel. Red Elk v. United States, 62 F.3d 1102, 1104 (8th Cir. 1995) (applying South Dakota law where a tribal police officer raped a woman he picked up on an Indian reservation); Champagne v. United States, 40 F.3d 946, 947 (8th Cir. 1994) (applying North Dakota law where alleged malpractice and consequently wrongful death occurred on an Indian reservation); Red Lake Band of Chippewa Indians v. United States, 936 F.2d 1320, 1325 (D.C. Cir. 1991) (applying Minnesota law where property damage occurred on an Indian reservation); Louis v. United States, 54 F. Supp. 2d 1207, 1211 (D.N.M. 1999) (applying New Mexico law where alleged medical negligence resulting in wrongful death occurred on an Indian reservation).

309. See Louis, 54 F. Supp. 2d at 1211 (concluding that tribal law should not be used directly under the FTCA or even under New Mexico law under a choice-of-law analysis); see also id. at 1210 n.5 ("The Court does not believe Congress intended such a result [as having tribal law govern the United States' liability in tort] when 
law would not be unprecedented because although courts generally apply state law in FTCA cases, when a tort in an FTCA case occurs in places like Puerto Rico, the U.S. Virgin Islands, or the Panama Canal Zone, courts apply the law of those places, which are not states but still have the ability to pass their own laws. ${ }^{310}$ This argument fails to account for the fact that none of those entities exist within the boundaries of a state. ${ }^{311}$ In other situations more analogous to the tribal context, like military bases and national parks, courts have applied state law in FTCA suits when actions happen in federal enclaves within states. ${ }^{312}$

The Cheromiah court went on to hold that the law of the Acoma Pueblo would find the New Mexico medical malpractices damages cap to be "repugnant." ${ }^{313}$ One problem with this argument is that the court cites a case, Louis $v$. United States, ${ }^{314}$ that considered a similar factual situation and chose to apply New Mexico law, including its damages cap, rather than tribal law. ${ }^{315}$ Furthermore, the Louis court does not analyze the tribe's position on medical malpractice caps. ${ }^{316}$

adopting the FTCA, as it strictly limits the parameters of a tort suit brought against the federal government."). Compare LaFromboise, 439 F.3d at 794 (citing Chips v. United States, No. Civ. 5:92-5025-AWD (D.S.D. Apr. 28, 1993), and Azure v. United States, No. Civ. 90-68-GF-PGH (D. Mont. May 9, 1991), as examples of courts declining to apply tribal law, although not discussing the depth at which the courts had addressed the issue or giving any more information about those cases), with Cheromiah, 55 F. Supp. 2d at 1306 (citing Chips and Azure but dismissing them as instances where the parties did not properly raise choice-of-law issues). The Chips and Azure decisions are not widely available.

310. See Cheromiah, 55 F. Supp. 2d at 1302 (collecting FTCA cases applying the laws of entities other than states).

311. See Bryant v. United States, 147 F. Supp. 2d 953, 957-58 (D. Ariz. 2000) (distinguishing the examples given in Cheromiah of places like Puerto Rico and Guam from federal enclaves located entirely within states and finding it to be significant that the Indian reservation in question was located entirely within the borders of Arizona); see also Brock v. United States, 601 F.2d 976, 979 (9th Cir. 1979) (arguing that place refers to locality and does not mean "the law of the entity which has jurisdiction over the situs of the negligent act”); Fed. Express Corp. v. United States, 228 F. Supp. 2d 1267, 1269 (D.N.M. 2002) ([E]ven if tribal jurisdiction concurrently extends to the claim at hand, the mere existence of jurisdiction is not determinative in deciding what 'law of the place' applies" in an FTCA action).

312. See, e.g., Rayonier Inc. v. United States, 352 U.S. 315, 318 (1957) (applying Washington law where the alleged tort happened while fighting a fire on public lands); Will v. United States, 849 F.2d 315, 317 (8th Cir. 1988) (applying Missouri law where an accident happened in a national park); Shankle v. United States, 796 F.2d 742, 744-45 (5th Cir. 1986) (applying Texas law where the tort occurred on a military base).

313. See Cheromiah, 55 F. Supp. 2d at 1309 (citing Louis for the proposition that the Acoma Pueblo courts disagreed on the acceptability of damages caps).

314. 54 F. Supp. 2d 1207 (D.N.M. 1999).

315. Id. at 1209-10 (considering the application of tribal law and rejecting this idea in favor of applying New Mexico law).

316. Cf. id. at 1210 n.5 (observing that "[i]n the District of New Mexico alone, for example, there are great differences between the many tribes and their approaches 
Once the Cheromiah court issued the order that tribal law would govern, the United States settled for an amount not exceeding New Mexico's damages cap, and the issue was never appealed. ${ }^{317}$

The court's logic in Cheromiah is deeply flawed, yet some commentators laud this decision as a singular victory over "outsider fears" that push courts to reject applying tribal law in FTCA cases. ${ }^{318}$ These charges of government prejudice against the tribes do not comport with the reality of Cheromiah. The health center where the negligent care in Cheromiah occurred served three different Indian tribes, two of which were completely separate pueblos, and the third was Navajo. ${ }^{319}$ Had the Cheromiahs' claim actually proceeded to trial applying Acoma Pueblo law, it would have created problems among the tribes sharing the facility, as the other tribes likely would not want to be subjected to the law of the Acoma Pueblo in the future. ${ }^{320}$ In recognition of this potentially problematic situation, just a year after Cheromiah, the Acoma Pueblo adopted the New Mexico Medical Malpractice Act in its entirety, including the cap on damages. ${ }^{321}$ This result diffuses the charges of animus, as the tribe ultimately adopted the provision that the government tried to take advantage of in Cheromiah.

Furthermore, courts cannot apply tribal law in FTCA cases if they cannot discern the tribal law. Commentators favoring the Cheromiah approach argue under the assumption that the district court was readily able to determine Acoma Pueblo law and that it was adequate for the situation. ${ }^{322}$ Some tribes, like the Navajo, do indeed have well-

to legal issues [,and] [i]n some instances, the difficulty in proving the existence and substance of any tribal law on the subject of the tort would be considerable").

317. See Pearson, supra note 286, at 699 (suggesting that the United States' desire to limit the precedential value of the case was a significant factor in the decision to settle). Pearson incorrectly claims that the United States settled the case for $\$ 675,000$, more than the New Mexico cap. Id. New Mexico law limits the amount of damages a plaintiff can recover for medical malpractice to $\$ 600,000$. N.M. STAT. ANN. \$ 41-5-6 (West 2012). Arizona State Law Journal published a correction noting that the United States' final settlement in Cheromiah was actually for $\$ 600,000$, and thus not for more than the New Mexico cap, although it was contingent on the Acoma hospital reallocating $\$ 75,000$ to use for emergency services in memory of the decedent. Errata, 33 ARIz. ST. L.J. xi (2001).

318. See Easterwood, supra note 295, at 474 (asserting that cases that fail to apply tribal law are "erroneous" and reflect prejudice against the tribes). But see id. (predicting that had Cheromiah been appealed, the "outsider fears" would have likely caused the ruling to be overturned).

319. Defendant's Response to Plaintiff's Motion for Partial Summary Judgment, supra note 306 , at 6 .

320. See id. (noting that the resulting precedent would subject one tribe to other tribes' law).

321. Id.

322. See Pearson, supra note 286, at 737 (observing that the Cheromiah court seemed to assume that tribal law on damages was clear and it conflicted with New 
established court systems from which federal courts may be able to reliably ascertain tribal law. ${ }^{323}$ Many tribes, however, do not have written codes and presumably, to ascertain the law of one of these tribes, the parties would have to hire tribal elders as expert witnesses. ${ }^{324}$ Even in Cheromiah, a closer look reveals that Acoma Pueblo law may not have been clear. ${ }^{325}$ There, the Acoma Pueblo filed an amicus brief to advise the court on their tribal law. ${ }^{326}$ The tribes themselves worried that the judge relied on "questionable precedent" and included a proposed process for responding to questions of unwritten tribal law along with its motion. ${ }^{327}$ Although the government ultimately settled and Acoma Pueblo law was never tested in court, these motions suggest that determining the law would have been extremely difficult.

Additionally, assuming for the sake of argument that a court applied tribal law as the law of the place in FTCA cases, the tribes

Mexico law); Easterwood, supra note 295, at 475 (furthering the idea of tribal law's accuracy by suggesting that New Mexico and the tribes should continue to develop tribal law for possible future use).

323. See, e.g., NAVAJO NATION CODE ANN. tit. 1, \$ 201 (2009) (establishing a basis for Navajo law); Harvey II, No. 08CV107 MCA/CG, 2011 BL 177075, at* 4-7 (D.N.M. June 30, 2011) (applying Navajo law), aff'd on other grounds, 685 F.3d 939 (10th Cir. 2012). But see Oliphant v. Suquamish Indian Tribe, 435 U.S. 191, 211-12 (1978) (recognizing "that some Indian tribal court systems have become increasingly sophisticated and resemble in many respects their state counterparts," but ultimately declining to allow tribal courts to try non-Indians), superseded by statute, Defense Department Appropriations Act, 1991, Pub. L. No. 101-511, § 8077, 104 Stat. 1856, 1892-93 (1990), as recognized in United States v. Lara, 541 U.S. 193 (2004); Ben v. United States, No. CV 04-1850-PCT-PGR, 2007 WL 1461626, at *4 (D. Ariz. May 16, 2007) (declining to use Navajo law as the law of the place in an FTCA case); 2000 Senate Tribal Tort Liability Hearing, supra note 101, at 20 (statement of Ethan M. Posner, Deputy Associate Att'y Gen.) (noting that even within the state of New Mexico there are "great differences" among the laws of the tribes).

324. See Pearson, supra note 286, at 740 (observing that "[t] ribal law differs from tribe to tribe, running the gamut from the detailed code and written decisions of the Navajo Nation, to tribes which operate entirely by customary law"). Additionally, "district judges expect adequate expert testimony on foreign law and the failure to produce it may be quite damaging to a litigant's case." 9A CHARLES Alan Wright \& Arthur R. Miller, Federal Practice and Procedure § 2444, at 34648 (3d ed. 2008) (footnote omitted); see, e.g., Twohy v. First Nat'l Bank of Chi., 758 F.2d 1185, 1194 (7th Cir. 1985) (finding the district court's analysis of Spanish law to be insufficient); Dulles v. Katamoto, 256 F.2d 545, 547 (9th Cir. 1958) (noting that although Japanese law was well established, the United States failed to prove the provision in question because it did not produce an experienced practitioner as a witness). But cf. Cheromiah, 55 F. Supp. 2d at 1308 (finding that the tribes were not within the definition of a foreign country).

325. See Pearson, supra note 286, at 739-40 (discussing the procedural posturing of Cheromiah in great detail and analyzing the involvement of the Acoma Pueblo courts).

326. Id.

327. Id. at 740 . 
would control access to that body of law. ${ }^{328}$ As noted previously, having the federal government's sovereign immunity protect the tribes creates perverse incentives not to cooperate with the DOJ, because the tribes ultimately do not pay the damages. ${ }^{329}$ The tribes would have to provide the DOJ with access to and instruction about their laws so that the DOJ could try to make an argument against recovery for a tribal member. ${ }^{330}$ This moral hazard would be even greater when a tribe lacks a written code at the time of trial, and could result in the tribal council formulating law as the dispute progresses to trial. ${ }^{331}$ Such an arrangement would be inconsistent with the American legal system and its notions of justice. ${ }^{332}$ In addition, it is entirely foreseeable that both parties to the litigation could hire tribal elders with competing interpretations of the law. ${ }^{333}$ Some commentators have suggested the use of certification procedures as a means for tribal courts to avoid problems of discerning tribal law. ${ }^{334}$ Such a solution could make the process more orderly but may not avoid the moral hazard of potentially making law

328. Id. (noting wide variations in the development of law amongst the tribes, ranging from published written codes to systems based entirely on customary law). Some tribal law, such as the Navajo statutes and court decisions, are recorded in English and can be found on Westlaw, while others are recorded in tribal languages or not recorded in writing at all.

329. See supra note 119 and accompanying text (reviewing the perverse incentives for the tribes not to cooperate with investigations).

330. See supra note 119 and accompanying text.

331. See Pearson, supra note 286, at 744 (suggesting the tribes have "centuries of reasons" for distrusting the federal government); see also Florey, supra note 157, at 1689 (observing that encouraging tribal courts to adopt more formal procedures so that federal and state courts can apply their laws may interfere with the cultural benefits that result from the tribes employing traditional methods of decisionmaking).

332. See John J. Harte, Validity of A State Court's Exercise of Concurrent Jurisdiction over Civil Actions Arising in Indian Country: Application of the Indian Abstention Doctrine in State Court, 21 AM. InDian L. REv. 63, 92 (1997) ("[T]he fundamental value differences between tribal and state justice systems are dramatically different. The very nature of tribal law mandates that only the tribal court, whose law is at issue, be authorized to apply it.").

333. See Pearson, supra note 286, at 741 (noting that when courts determine foreign law, the process involves witness testimony). The FTCA, however, does not waive the United States' sovereign immunity for torts arising in foreign countries. 28 U.S.C. \$ 2680(k) (2006); see supra notes 288-293 and accompanying text (discussing the FTCA's foreign tort prohibition).

334. See CoHEN's Handbook of Federal Indian Law, supra note 46, § 7.06[2], at 654 (suggesting certification to tribal courts is the best way for state courts to address questions of tribal law); Vanessa J. Jiménez \& Soo C. Song, Concurrent Tribal and State Jurisdiction Under Public Law 280, 47 AM. U. L. REV. 1627, 1701 \& n.419 (1998) (arguing that certifying tribal law questions to tribal courts furthers collaboration and communication between the tribes and the federal government). 
after the fact. ${ }^{335}$ Further, it would certainly delay the proceedings considerably. ${ }^{336}$

To date, many courts have considered the issue of applying tribal law and decided against it, ${ }^{337}$ but only one case has followed the decision in Cheromiah. ${ }^{338}$ In Harvey v. United States, ${ }^{339}$ a federal district court in New Mexico found Navajo law to be the law of the place in an FTCA suit alleging medical malpractice. ${ }^{340}$ The court was able to cite Navajo law, because that tribe has a well-developed legal system with a published code and widely-available reported common law. ${ }^{341}$ Still, the court had to fill in gaps in the law with provisions from Arizona law. ${ }^{342}$ Ultimately the U.S. Court of Appeals for the Tenth Circuit affirmed the district court's finding for the United States but refused to comment on the choice-of-law issue, noting that the plaintiff clearly failed to establish the elements of his case under both

335. Cf. Harte, supra note 332, at 96 (noting that to avoid instances of the tribes filling gaps in their law after the fact, some courts have found that the tribes are not asserting their sovereignty where they have no written laws addressing the issue in question).

336. See Pearson, supra note 286, at 742 (conceding that the certification procedure would be "time consuming," although ultimately arguing that it is the best way for federal courts to determine tribal law).

337. See LaFromboise v. Leavitt, 439 F.3d 792, 795 (8th Cir. 2006) (observing the "uncertainty and potential for expanded liability" that would flow from applying tribal law and deciding instead to use North Dakota law); Ben v. United States, No. CV 04-1850-PCT-PGR, 2007 WL 1461626, at *2 (D. Ariz. May 16, 2007) (finding that courts have consistently taken the position that state law should apply even when the negligent act took place on Indian land); Fed. Express Corp. v. United States, 228 F. Supp. 2d 1267, 1269-70 (D.N.M. 2002) (noting that even if the plaintiffs could establish concurrent jurisdiction with the tribal courts, it would not make tribal law the law of the place, and applying New Mexico law); Bryant v. United States, 147 F. Supp. 2d 953, 959-60 (D. Ariz. 2000) (suggesting that the application of tribal law would be an "abrupt judicial departure" from precedent and applying New Mexico law); Louis v. United States, 54 F. Supp. 2d 1207, 1210 \& n.5 (D.N.M. 1999) (charging that the use of tribal law would violate congressional intent behind the FTCA and applying New Mexico law); $c f$. Williams v. United States, 242 F.3d 169, 176 n.2 (4th Cir. 2001) (applying North Carolina law because even if the court applied tribal law, the tribe in question had no law on emergency medical treatment and would look to federal and North Carolina law).

338. See Harvey v. United States (Harvey I), No. 08CV107 MCA/RLP, 2009 BL 207883, at *5 (D.N.M. Sept. 29, 2009) (equating place with a political entity); $c f$. Quechan Indian Tribe v. United States, 535 F. Supp. 2d 1072, 1103-04 (S.D. Cal. 2008) (endorsing the Cheromiah approach in theory but ultimately concluding that the tribe would not have jurisdiction over a nonmember to enforce the tribal law in question and therefore looking to California law).

339. No. 08CV107 MCA/RLP, 2009 BL 207883 (D.N.M. Sept. 29, 2009), aff'd on other grounds, 685 F.3d 939 (10th Cir. 2012).

340. Id. at $* 9$.

341. See Harvey II, No. 08CV107 MCA/CG, 2011 BL 177075, at *4-7 (D.N.M. June 30,2011 ) (citing nine separate Navajo cases), aff'd on other grounds, 685 F.3d 939.

342. Id. at $* 7$. 
Arizona and Navajo law. ${ }^{343}$ By failing to address the issue directly, the court in Harvey III left the possibility of tribal law open to future cases in the Tenth Circuit.

Unlike the Tenth Circuit in Harvey III, in LaFromboise v. Leavitt, ${ }^{344}$ the Eighth Circuit addressed the choice-of-law issue directly. ${ }^{345}$ The court noted that while the plain meaning of the statute - "the law of the place" suggests Congress's contemplation of a single source of governing law, an alternative interpretation would require an inquiry into a political entity's civil authority to cover alleged negligence actions arising against private parties, "without any guiding principle" to determine the governing law in cases of concurrent jurisdiction between state and tribal courts. ${ }^{346}$ In addition, often these cases involve claims against both tribal and non-tribal members, creating an overlap of choice of laws. ${ }^{347}$ The Indian tribes retain the power to use tribal law "to punish tribal offenders, ... to determine tribal membership, to regulate domestic relations among members, and to prescribe rules of inheritance for members." ${ }^{\text {348 }}$ The tribes, however, generally do not have jurisdiction over nonmembers. ${ }^{349}$ Interpreting tribal law to be the law of the place would require courts to apply both tribal and state law in the same case when parties to a single case are comprised of both tribal members and nonmembers, because tribal law may not apply to the nonmembers. ${ }^{350}$ Courts, however, have consistently refused to apply the laws of two different states exercising concurrent jurisdiction over the site of the incident in FTCA cases. ${ }^{351}$ Therefore, applying tribal and state law to the same claims is incongruent with the courts' dominant construction

343. See Harvey v. United States (Harvey III), 685 F.3d at 950-56 (expressly declining to decide the issue of whether Arizona or Navajo law would govern).

344. 439 F.3d 792 (8th Cir. 2006).

345. Id. at 794 .

346. Id.

347. See 2000 Senate Tribal Tort Liability Hearing, supra note 101, at 20 (statement of Ethan M. Posner, Deputy Associate Att'y Gen.) (arguing that the exercise of jurisdiction over both tribal and non-tribal defendants would result in applying different law to different defendants in the same action, which violates the FTCA's plain language).

348. Montana v. United States, 450 U.S. 544, 564 (1981).

349. Id. at 565

350. Id.

351. See, e.g., Brock v. United States, 601 F.2d 976, 976-79 (9th Cir. 1979) (applying Washington law where negligence occurred in Washington causing a worker to fall to his death from a scaffold into the Columbia river, over which Oregon and Washington have concurrent jurisdiction). 
of the FTCA because it can lead courts to apply the law of two different places. ${ }^{352}$

Furthermore, if courts did apply tribal law, federal employees could be subject to the laws of over 550 different tribes, which extends beyond the scope of what Congress contemplated in enacting the FTCA. $^{353}$ By incorporating the law of the fifty states into the FTCA, Congress did intend for some variation in FTCA jurisprudence. ${ }^{354}$ The tribes vary drastically in the development of their legal systems, however, and it may be difficult to ascertain the laws of many of the tribes. ${ }^{355}$ Based on these considerations, virtually all courts have concluded that Congress could not have meant to subject the United States to this much variability, uncertainty, and potentially increased liability. ${ }^{356}$

\section{Using state choice-of-law rules to apply tribal law}

Courts should not use state choice-of-law rules to provide a backdoor way to apply tribal law as some commentators suggest. ${ }^{357}$ Initially states used a rigid construction of conflict of law based on lex loci delicti, the law of the place where the wrong occurred. ${ }^{358}$ During the mid-twentieth century, however, states began adopting more flexible standards and today most conflict-of-law provisions choose the law of the state with the "most significant relationship" to the incident. ${ }^{359}$ Applying state law and then choosing tribal law through

352. See LaFromboise v. Leavitt, 439 F.3d 792, 794 (8th Cir. 2006) (finding that "Congress contemplated a single source of governing law").

353. See id. at 795 (remarking that there would be great administrative difficulties associated with interpreting the law of the place so as to subject the United States to the laws of all of the Indian tribes).

354. See Pearson, supra note 286, at 710 (observing the potential for drastically different outcomes in similar situations because of wide variances in tribal law under a construction of the FTCA that encourages federal courts to apply tribal law as the law of the place).

355. See supra note 323 (discussing differences in the legal systems among the tribes).

356. See LaFromboise, 439 F.3d at 795 (suggesting that Congress could not possibly have intended to subject the United States to the laws of so many tribes because it would cause extreme administrative difficulties); Louis v. United States, 54 F. Supp. 2d 1207, 1210 n.5 (D.N.M. 1999) (noting the differences in how the tribes approach legal issues and arguing that in some instances "the difficulty in proving the existence and substance of any tribal law on the subject of the tort would be considerable").

357. See Florey, supra note 157, at 1676 (refuting objections to using state choiceof-law rules to choose tribal law).

358. Id. at 1651; see RESTATEMENT (FIRST) OF CONFLICT OF LAWS $§ 377$ (1934) ("The place of wrong is in the state where the last event necessary to make an actor liable for an alleged tort takes place.").

359. Florey, supra note 157, at 1654-55; see RESTATEMENT (SECOND) OF CONFLICT OF LAWS $§ 145(1)$ (1971) ("The rights and liabilities of the parties with respect to an 
conflict of laws would produce the same result as in Cheromiah but would arrive there by different reasoning. Still, courts in states using both approaches to resolve a conflict of state laws have concluded that tribal law should not be applied in FTCA cases. ${ }^{360}$ In Louis, a federal district court in New Mexico used the lex loci deliciti approach and found New Mexico law to apply because the plaintiff died in an Albuquerque hospital, rather than in Indian country. ${ }^{361}$ Commentators argue that this approach allows for application of tribal law under a different set of facts. ${ }^{362}$ The Louis court's discussion of its strong reservations against applying tribal law, however, suggests that those commentators may be overly optimistic. ${ }^{363}$ Furthermore, under the modern approach the difficulty in ascertaining precisely what tribal law is for a given tribe weighs against choosing tribal law. ${ }^{364}$

Even though most courts have rejected the use of tribal law to govern these disputes, the statutory scheme governing tribal contracting leaves this possibility open, which could potentially subject the United States to liability based on tribal law that may be nearly impossible to ascertain in some cases. ${ }^{365}$ Tribal law is not objectively better or worse than state law, but the practical difficulties in ascertaining tribal law make it inconsistent with the FTCA. ${ }^{366}$

issue in tort are determined by the local law of the state which, with respect to that issue, has the most significant relationship to the occurrence and the parties ....”).

360. Compare Louis, 54 F. Supp. 2d at 1210-11 (applying the lex loci delicti standard and concluding that New Mexico law applied), with Ben v. United States, No. CV 041850-PCT-PGR, 2007 WL 1461626, at *2-4 (D. Ariz. May 16, 2007) (acknowledging Arizona's use of the "most significant relationship" standard but finding tribal law not to be an acceptable option and therefore not getting to the issue).

361. See Louis, 54 F. Supp. 2d at 1211 (finding that the result of the negligence manifested itself off the reservation).

362. See Florey, supra note 157, at 1668 (arguing that the Louis court left the door open for application of tribal law in future cases); $c f$. Pearson, supra note 286, at 744 (suggesting new fact patterns could make tribal law more viable in FTCA cases).

363. See Louis, 54 F. Supp. 2d at 1210 n.5 (cataloguing concerns about applying tribal law under the FTCA and concluding that interpreting the law of the place to be tribal law would constitute an expansion of the FTCA that is best left for Congress).

364. See Pearson, supra note 286, at 740 (conceding that the difficulty of determining the law may in some instances make it harder for courts to choose tribal law); see also RESTATEMENT (SECOND) OF CONFLICT OF LAWS $§ 6(2)(\mathrm{g})$ (1971) (listing ease of determining the law as one of the factors for courts to consider in choosing what law to apply).

365. See supra note 337 (arguing this application is not what Congress intended when it passed the FTCA).

366. See FDIC v. Meyer, 510 U.S. 471, 478 (1994) (“[W]e have consistently held that [the FTCA's] reference to the 'law of the place' means law of the State . . .."). While there may be instances where the tribes have written law on the relevant subject, allowing the selective use of tribal law in such cases puts courts in the uncomfortable position of having to judge the adequacy of tribal law. 
Further, using tribal law violates the principle of not making the United States' liability dependent on another sovereign's laws. ${ }^{367}$

The potential pitfalls of applying tribal law expose another reason why Congress should reconsider extending the FTCA to cover tribal contractors and replace it with private insurance. ${ }^{368}$ Even if Congress fails to advance a comprehensive solution, it should at least specify that state law, rather than tribal law, should apply in these situations.

Congress took the drastic step of extending the FTCA to keep costs down for the tribes entering into Self-Determination Act contracts, yet after more than twenty years, most prudent tribes continue to purchase private insurance due to uncertainty about the FTCA. ${ }^{369}$ The current practice is wasteful in that the tribes save little money and the United States ends up paying extra. ${ }^{370}$ Congress had a laudable goal in helping the tribes enter into Self-Determination Act contracts, but using the FTCA failed to accomplish that goal, and the experiment in extending it to the Indian tribes should be abandoned.

\section{SUGGESTIONS FOR REFORM: CONGRESS SHOULD REPLACE FTCA COVERAGE FOR TRIBAL CONTRACTORS WITH SUBSIDIZED PRIVATE INSURANCE}

Congress sought to protect the tribes from the costs of buying expensive liability insurance when it extended the FTCA to cover the tribes' torts. ${ }^{371}$ Replacing FTCA coverage with subsidized private insurance would simplify the process and cut costs for both the federal government and the tribes. According to a BIA study commissioned by Congress, however, many tribes opt to purchase private insurance coverage due to either lack of certainty or

367. See United States v. Spelar, 338 U.S. 217, 221 (1949) ("Congress was ready to lay aside a great portion of the sovereign's ancient and unquestioned immunity from suit, [but] it was unwilling to subject the United States to liabilities depending upon the laws of a foreign power."). But cf. Cherokee Nation v. Georgia, 30 U.S. (5 Pet.) 1, 17 (1831) (categorizing the tribes as "domestic dependent nations"); Cheromiah v. United States, 55 F. Supp. 2d 1295, 1308 (D.N.M. 1999) (finding that because the tribes were not foreign countries this exception could not apply).

368. See infra Part III (developing the recommendation for replacing the FTCA with private insurance further).

369. See 2000 Senate Tribal Tort Liability Hearing, supra note 101, at 11 (statement of Michael Anderson, Deputy Assistant Secretary for Indian Affairs) (revealing that ninety percent of tribes entering into Self-Determination Act contracts buy private insurance).

370. See 2000 GAO REPORT, supra note 56, at 5 (noting that the federal government pays for private insurance through Self-Determination Act contract support funds in addition to paying for FTCA judgments and settlements).

371. See 1987 Senate Self-Determination Act Hearing, supra note 57, at 1 (statement of Sen. Inouye) (discussing the problem of "indirect costs" associated with tribal contracting). 
awareness of the extent of FTCA coverage. ${ }^{372}$ This practice is wasteful for both the tribes and the federal government. Furthermore, the GAO report identified some major problems with applying the FTCA to tribal contractors, particularly in the area of law enforcement. ${ }^{373}$

The Campbell and Gorton bills from 1998 each contain ideas that could usefully guide the analysis of proposals for reform. The Gorton bill, unlike the Campbell bill, proposed to end the experiment of covering tribal contractor torts with the FTCA. ${ }^{374}$ That bill's sweeping scope, however, seems to have rankled some key members of the Senate and thus has never been passed. ${ }^{375}$ The problem with the Gorton bill is that it goes too far into the thorny issue of abrogating tribal sovereignty, rather than focusing on tribal contractor torts. ${ }^{376}$ The Self-Determination Act already waives tribal sovereign immunity for cases arising from torts committed by tribal contractors and there is no need, from a tort perspective, to go any further. ${ }^{377}$ The Campbell bill, on the other hand, does not extend far enough and assumes that the line between what the FTCA covers and what private insurance covers is clear. ${ }^{378}$ The Campbell bill focuses on extending insurance to cover areas left untouched by the FTCA. ${ }^{379}$

A solution to the problem of liability coverage for FTCA contractors would be to combine elements from both bills. This solution would completely remove FTCA coverage from tribal contracting and instead focus on assisting the tribes in acquiring comprehensive private liability insurance.

372. See 2000 Senate Tribal Tort Liability Hearing, supra note 101, at 87 (observing that neither the tribes nor insurance companies understand what the FTCA covers and are unable to use it effectively).

373. See generally 2000 GAO REPORT, supra note 56, at 31 fig.6 (illustrating the poor fit between the FTCA and tribal contractors in graphic form).

374. See American Indian Equal Justice Act, S. 1691, 105th Cong., § 1 (1998).

375. See 1998 Senate Tribal Sovereign Immunity Hearing, supra note 91, at 3 (statement of Sen. Daniel K. Inouye, Vice Chairman, S. Comm. on Indian Affairs) ("Given this dramatic and some would say radical departure from the wellestablished course of our history and our laws, I believe it is only natural to inquire what may be in law or in fact that would require us to so abruptly abandon what has stood for so long.").

376. See American Indian Equal Justice Act, S. 1691, § 4 (a) (waiving tribal sovereign immunity virtually in its entirety, beyond what would be required to replace the FTCA with subsidized private insurance).

377. See supra note 89 (discussing the waiver of tribal sovereign immunity).

378. See S. 2097, 105th Cong. §201(b) (1998) (improving coordination between the tribes and the federal government on insurance issues); cf. 2000 GAO REPORT, supra note 56, at 35 (noting ongoing uncertainty about the extent of FTCA coverage).

379. See 105 Cong. REc. 9867 (1998) (statement of Sen. Ben Nighthorse Campbell) (explaining that his bill was "intended to provide a remedy in tort situations for those tribes that are not covered by the Federal Tort Claims Act, or covered by private secured liability insurance”). 
Congress should require the tribes to obtain insurance, as it did before 1990, and help the tribes pay for insurance through increased contract support funds. ${ }^{380}$ Under this scheme, when an individual is injured, he or she can settle with or bring suit against the insurance company without worrying that sovereign immunity will serve as a bar to recovery. Furthermore, the tribes have an incentive to undertake loss-reduction activities because doing so will bring down their insurance premiums. ${ }^{381}$

Critics would likely suggest that this kind of measure degrades the tribes by treating them like corporations rather than sovereign nations. ${ }^{382}$ They would argue that taking away the FTCA's discretionary function protection would result in the tribes being subject to more liability than the government. ${ }^{383}$ However, even though the tribes are indeed sovereigns, Congress intended the FTCA to address the United States' sovereign immunity, not all sovereigns. Therefore, the FTCA should not protect the tribes from liability. ${ }^{384}$ Applying the discretionary function exception, like other FTCA provisions, is problematic because it exposes the underlying tensions created by a system in which a limited waiver of one sovereign's immunity protects another sovereign from liability. ${ }^{385}$

380. The Self-Determination Act mandates that Congress pay tribal contract support costs in full, but Congress often fails to appropriate enough funds to cover actual costs by setting funding caps. Salazar v. Ramah Navajo Chapter, 132 S. Ct. 2181, 2187 (2012). The Supreme Court held in 2012 that traditional government contract rules would govern and the "[g] overnment must pay each tribe's contract support costs in full." Id. at 2186. The Supreme Court determined that if the government fails to pay the promised Self-Determination Act contract support funds, the tribal contractor can sue under the Contract Disputes Act and judgments will be paid from the Judgment Fund. Id. at 2193. Prior to Ramah, the tribes were skeptical of any solution proposing increased contract support funding because they could not be assured that they would receive the funds promised. After Ramah, such concerns are unlikely to create barriers to the tribes receiving contract support funds. See id. at 2195 (underscoring that the government rather than the tribe "must bear the consequences of Congress' decision to mandate that the Government enter into binding contracts for which its appropriation was sufficient to pay any individual tribal contractor, but 'insufficient to pay all the contracts the agency has made."” (quoting Cherokee Nation v. Leavitt, 543 U.S. 631, 637 (2005))).

381. Cf. Letter from Edward B. Cohen to Jim Wells, supra note 119, at 2 (observing that ordinary incentives for loss-reduction activities are not present in tribal contracting because the federal government, rather than the tribes, is held responsible for the torts committed by tribal contractors).

382. E.g., 1998 Senate Tribal Sovereign Immunity Hearing, supra note 91, at 3 (statement of Sen. Daniel K. Inouye, Vice Chairman, S. Comm. on Indian Affairs).

383. See Schlosser, supra note 89 , at 338 (making the point that removing the discretionary function protection will lead to more liability than the United States would have had if it provided the functions directly to the tribes through the BIA).

384. See supra Part II.A (discussing sovereign immunity and the theoretical problem of applying the FTCA to tribal contractors).

385. See supra note 116 (highlighting the differences between the United States' sovereign immunity and tribal sovereign immunity). 
Arguing against FTCA protection for tribal contractors does not insinuate that the tribes are careless and undeserving of assistance. As part of the United States' continued trust relationship with the tribes, the government should work to facilitate Indian selfgovernance and help the tribes cover the costs of carrying out SelfDetermination Act contracts, including insurance. ${ }^{386}$ Rather than haphazardly using the FTCA to shield the tribes from liability, Congress should assist the tribes in carrying out Self-Determination Act contracts in a way that is fiscally responsible and transparent. ${ }^{387}$

The funds to pay tort judgments against tribal contractors providing services under the Self-Determination Act should be appropriated by Congress, rather than given out automatically through the Judgment Fund. ${ }^{388}$ Integrating this funding into a more regular budgeting process would further the goal of Indian selfgovernance in that the tribes would still be protected against tort liability but would have to take an active role in the process.

Nothing prevents individual tribes from fashioning statutes like the FTCA to dictate their sovereign immunity and tort liability relating to their members. ${ }^{389}$ A tribal statute could very well include protection for discretionary functions of tribal employees. Such a statute, modeled on the FTCA, could also include an administrative claim requirement to encourage settlement.

386. See Statement on Congressional Passage of Tribal Law and Order Legislation, 2010 DAILY COMP. PRES. DOC. 1 (July 21, 2010) (suggesting the United States is still committed to facilitating tribal autonomy through Self-Determination Act contracts). See generally Nell Jessup Newton, Enforcing the Federal-Indian Trust Relationship After Mitchell, 31 CATH. U. L. REV. 635, 635-36 (1982) (discussing the trust relationship between the federal government and the Indian tribes).

387. Critics suggest that the Judgment Fund is not transparent because there is no systematic way to track how much the United States pays out of the fund, which is not subject to the traditional appropriations process. See Judgment Fund Transparency Act of 2011, H.R. 1446, 112th Cong. $\$ 2$ (2011) (proposing reform by requiring all judgments paid out of the Judgment Fund to be posted on a website). The Judgment Fund Transparency Act has no co-sponsors and has not received any committee attention. Bill Summary $\mathcal{E}$ Status, H.R. 1446, LIBRARY OF CONGRESS, http://thomas.loc.gov/cgi-bin/bdquery/z?d112:H.R.1446: (last visited Nov. 8, 2012).

388. See Figley, supra note 20, at 75-77 (discussing the history of the Judgment Fund); $i d$. app. E at 145 (providing a sample letter with the information needed to receive payment from the Judgment Fund).

389. See Nevada v. Hicks, 533 U.S. 353, 359 (2001) (noting that " the inherent sovereign powers of an Indian tribe do not extend to the activities of nonmembers of the tribe' except to the extent 'necessary to protect tribal selfgovernment or to control internal relations" (quoting Montana v. United States, 450 U.S. 544, 564-65 (1981))). 


\section{CONCLUSION}

Using the FTCA to cover torts committed by tribal contractors contravenes the FTCA both in theory and in practice. Congress extended the FTCA to cover tribal contractors to try to facilitate more contracting, but it failed to consider the far-reaching implications of the extension.

Applying a waiver of the United States' sovereign immunity to tribal sovereigns convolutes the logic behind FTCA jurisprudence in numerous areas. It muddies the application of the FTCA's discretionary function protection. Courts have struggled to determine the extent to which the tribes can exercise the discretion that is usually reserved only for federal employees and expressly withheld from contractors. Furthermore, applying the FTCA to tribal contractors makes it hard to determine when employees are to be considered within the scope of their employment, a key determination in evaluating FTCA liability. The system breaks down even further with tribal law enforcement officers, which is one of the main areas for which the tribes enter into Self-Determination Act contracts. Here, a loophole bars government liability for tribal contractor actions where the victim could otherwise proceed if the tortious officer worked directly for the government. These cases also raise choice-of-law issues, leading to the possibility that courts could apply tribal law rather than federal law. Courts may, however, have trouble accurately discerning tribal law, and applying another nation's laws is inconsistent with the FTCA's rule against applying the laws of foreign nations.

Although Congress sought to simplify liability coverage for tribal contractors by extending the FTCA, in practice, the current statutory scheme has only created more confusion. Courts have produced inconsistent and bizarre results, causing uncertainty over coverage. As a result, savvy tribes with many Self-Determination Act contracts often decide to play it safe and opt to purchase private liability insurance that is duplicative of whatever coverage the FTCA provides. Congress's "solution" not only fails to solve or mitigate the problem for the tribes, but it also causes the government to incur the extra cost of defending related cases.

Congress should abandon its experiment of using the FTCA to cover tribal contractors and should instead help the tribes purchase private insurance to protect them from liability incurred while carrying out Self-Determination Act contracts. Doing so would not downgrade the tribes' sovereign status. Instead, helping the tribes purchase private insurance would empower the tribes to take a more 
active role in self-governance. As the tribes undertake more SelfDetermination functions, they must take on increased responsibility if they hope to achieve true self-determination. 